\title{
Framework for a Chemical Substance Reporting System
}

\author{
Sukhraj Singh Takhar ${ }^{1, *}$, Kapila Liyanage ${ }^{2}$ \\ ${ }^{1}$ Materials Management and Chemical Reporting, Assent Compliance Inc. \& PhD Research Student, College of Engineering and \\ Technology, University of Derby, Derby, DE22 3AW, United Kingdom.
}

${ }^{2}$ College of Engineering and Technology, University of Derby, Derby, DE22 3AW United Kingdom.

\begin{tabular}{l} 
A R T I C L E I N F O \\
\hline Article history: \\
Received: 11 August, 2018 \\
Accepted: 19 October, 2018 \\
Online: 25 October, 2018 \\
\hline Keywords: \\
Material compliance reporting \\
Material declarations \\
Supply chain management \\
Chemical regulation
\end{tabular}

\begin{abstract}
A B S T R A C T
In this paper a chemical substance reporting system is presented to enable industry to assess the impacts of increasing chemical regulations. Chemical regulations impose the need to monitor, control and restrict the use of hazardous substances. As chemical substances become more regulated, industry requires mechanisms to identify potential business continuity risks, posed by increased regulation. A chemical reporting system is one such mechanism that identifies chemical substances used on their (i) own, (ii) in mixtures, (iii) in materials, (iv) in internally defined articles (products) and (v) from articles (products) procured from the supply chain. The chemical reporting system will contrast product related information against chemical regulation substance lists, identifying the applicable reporting obligations and potential supply chain risks.
\end{abstract}

\section{Introduction}

Regulatory control is a method in which governments can impose a set of measures upon society to act in a certain manner. The development of new chemical substances gathered pace following the end of the second world war, where the vast amount of new chemicals at the time were being introduced to market at a rapid rate, with much reduced testing cycles. Following the Thalidomide and Asbestos scandals, chemical regulations first began to appear during the 1960's [1].

The core aims of chemical regulations are to limit the use of hazardous substances, by applying appropriate monitoring, control and restriction measures [2].

Chemical regulations within Europe have evolved from regulators reacting to chemical substance data, when hazards become known, as in the case of the Thalidomide and Asbestos scandals, to requiring industry to provide data on regulated chemical substances within products in order to gain access to the market, this coined the term 'no data no market'.

Chemical regulations such as the European Union (EU) Restriction of Hazardous Substances (RoHS) [3, 4]. EU Registration Evaluation Authorisation and restriction of CHemicals (REACH) [5] and other international regulations based on both EU RoHS and EU REACH have resulted in industry

\footnotetext{
*Sukhraj Singh Takhar, Email: Raj.Takhar@assentcompliance.com
}

having to generate vast amounts of information in relation to chemical substances used in articles (products) $[6,7,8]$.

A feature of traditional engineering organizations [9] is to compartmentalize data within specific functional areas, which results in multiple sub-systems storing data. This makes the process of identifying and collating chemical substance related information difficult.

Chemical regulations will aim to regulate more and more hazardous substances over time, this results in industry having to develop systems which record the use of chemical substances. Not understanding internal and supply chain usage of hazardous substances has the potential to create business continuity risks, where the hazardous chemicals substances become further regulated.

This paper contributes to chemical substance reporting literature by identifying a research gap of multiple organisational data silos, which currently store the required data elements. The purpose of this paper is to derive a set of data tables which could then be applied to existing systems or create a new system (cloud based, data warehouse, access database, etc) to perform chemical substance reporting activities.

\section{Methodology}

This study follows a three-step approach to conduct the literature review. The research consisted of (1) initial literature 


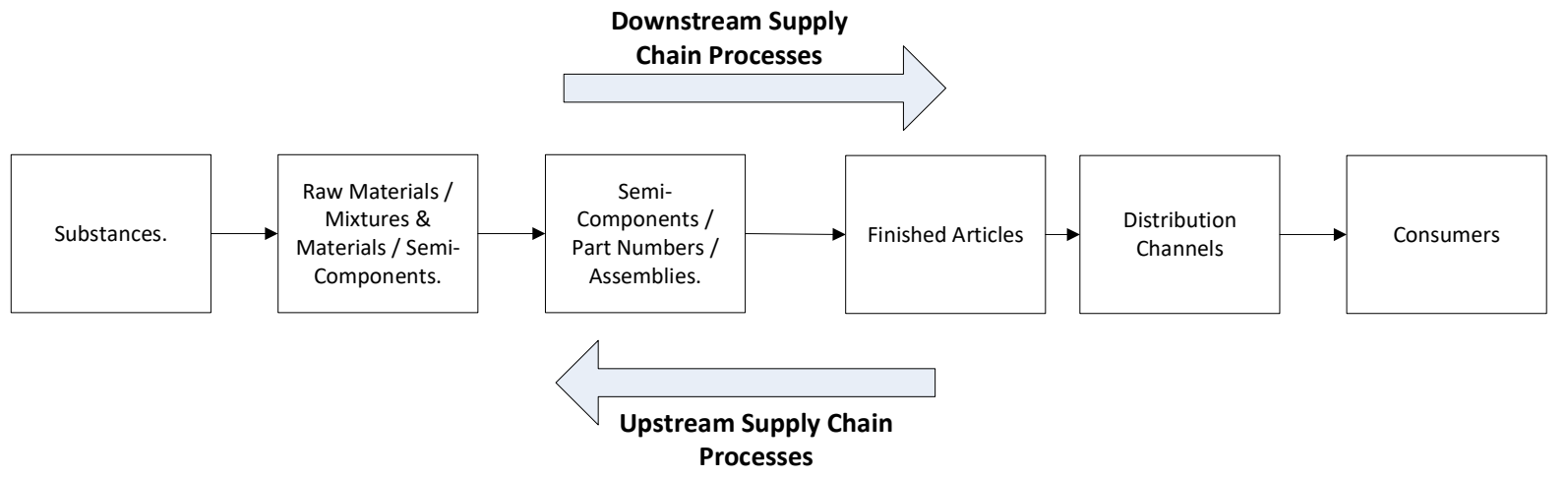

Figure 1. Article transformation cycle (simple supply chain)

search against chemical regulations, industry examples of chemical reporting systems appearing within the title of an article. selecting the most relevant articles; (2) cross-referencing supply chain management articles; (3) application of previous work experience in development and implementation of chemical reporting systems within the Aerospace and Defence sector, this includes expert interviews with users of previously implemented systems.

\section{Findings}

\subsection{Supply Chain Evolution}

The term 'Article Transformation Cycle' is the process of utilising raw materials, processing substances and mixtures to produce finished articles. Figure 1 presents the article transformation cycle.

Supply chains are a collection of organizations / elements, selling / flowing articles and services. The traditional supply chain focused on: (1) maintaining deliverables; (2) reducing costs; (3) increasing customer satisfaction levels [10,11] Supply chains evolved from simple, labour intensive articles through to highly complex modern articles [12].

Understanding the article transformation cycle is important to see where chemical substances, mixtures and materials are being applied to articles.

\subsection{Impacts of Chemical Regulations}

Each chemical regulation presents industry with potentially new impact(s) as shown in Figure 2. Chemical regulations define lists of substances against which specific actions / obligations are to be undertaken: (1) regulatory notifications; (2) supply chain declarations; (3) customer declarations; (4) safe use guidance for consumers and article users; (5) continued authorized use of a substance request; (6) through to prohibited use of a substance, this information requires substance identification at the article level $[13,14]$.

As the number of chemical regulations increased, so too has the number of reportable substance lists $[15,16,17]$. This has resulted in specific industry sectors having to develop harmonized substance lists for their supply chains to report against, these have appeared in the Automotive [18], Electronics [19, 20] and AD sectors [21].

\subsection{Traditional Organizational Information Flows}

To develop a chemical reporting system, existing data silos and flow of information need to be examined. Figure 3 presents a systems diagram, based on expert interviews:

- Materials function: generate the specifications (material/ process based) with details of applicable chemical substance(s); mixture(s) or material(s) .

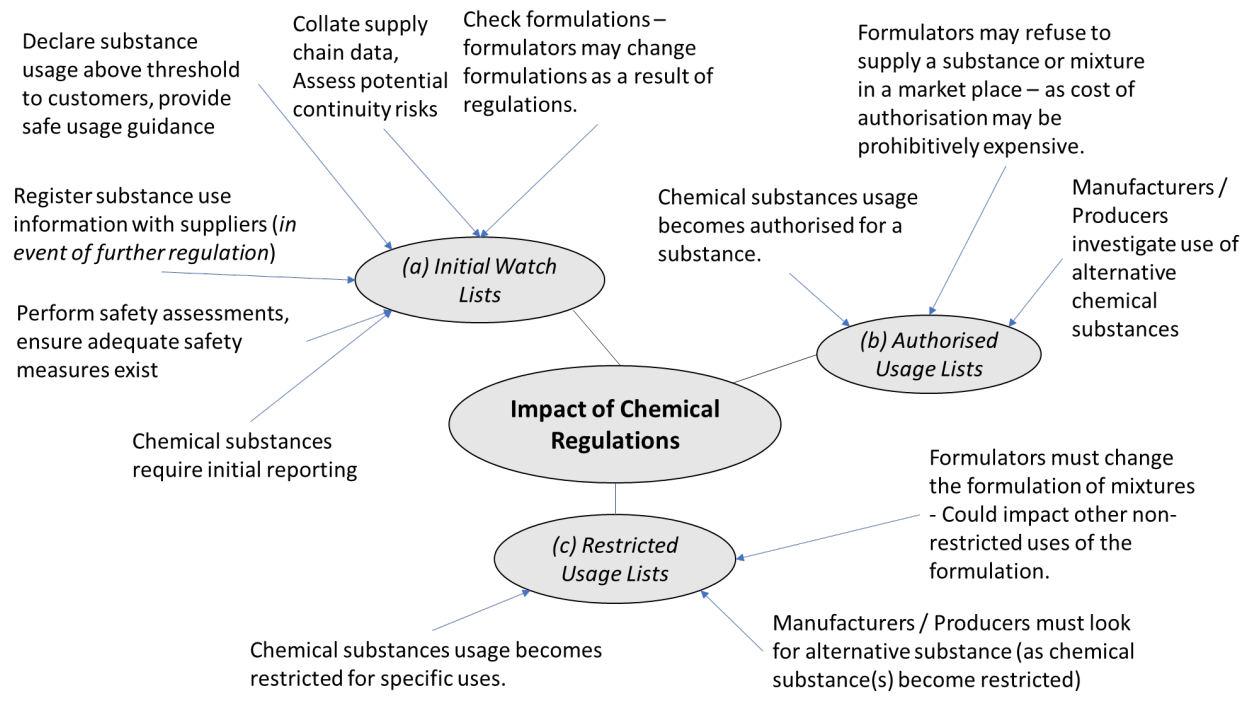

Figure 2. Impacts of chemical regulations 
- Design function: generate individual engineering drawings for article(s) referencing specifications.

- Purchasing function: responsible for purchasing articles from supply chain.

- Engineering function: responsible for article transformation cycle for internal produced articles.

- Stores function: receipt, dispatch articles.

- Compliance function: (1) highlight potential business continuity risks of articles which contain regulated substances. (2) perform regulatory reporting and obligation (notifications / authorisation) tasks.

- Health and Safety function: ensure safety of employees, users of articles and the environment.

- Sales function: communicate with the customer and provide any regulatory reporting as required.

- Quality function: maintain consistent quality procedures and practices across the organization.

- Chemical regulators: define chemical substance lists and applicable obligations.

- Customers: consumer(s) of articles.

Issues arise where variability in data consistency and quality causes incorrect analysis taking place.

\subsection{Aerospace and Defence (AD) Sector Organizational Information Flows}

Based on expert interviews with companies from the $\mathrm{AD}$ sector, the following common practices were identified:
- Specifications: (1) configuration management appears to be limited; (2) standard practices focus on updating specification data with additional substance and mixture information as opposed to creating new specification numbers, this was primarily to avoid the cost updating geometry drawings with new specification numbers.

- Drawings: (1) drawings were not altered unless a change occurred to an article fit, form or function; (2) with specifications detailing the material and process specification data.

- Contracts: (1) supplier agreements; (2) audit data (3) payment terms and conditions; (4) required document(s): (5) statements of conformity; (6) supplier chemical substance declarations; (7) conflict mineral reporting; (8) safe use information; (9) industry reporting standards, etc.

- Data ambiguity: poor quality control from (1) requirements capture; (2) configuration management of specification data cause issues, as shown in Figure 4.

- Data flows: a typical finished AD article may consist of multiple sub-articles, all of which need to be collated and rolled up, with the chemical substance reporting system.

Evolving supply chains: AD supply chains are not simple, as a result of a number of vertical and horizontal integrations, it is possible at one level for customers and competitors to be suppliers at another level, for example Bombardier are both a component supplier and a customer for Rolls-Royce aero engines, if as a supplier it does not supply adequate substance information, this will make it hard for them to request full substance information as

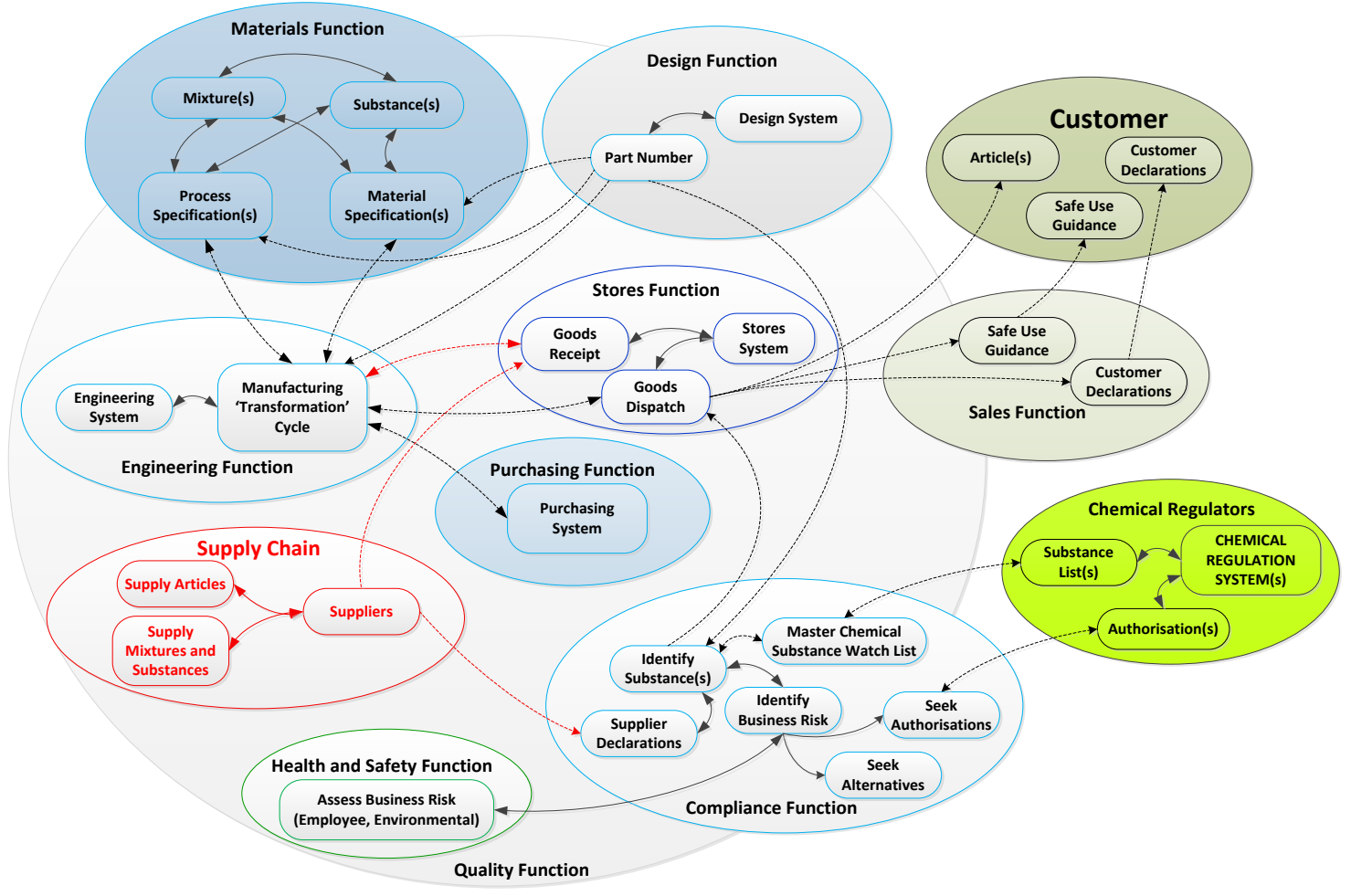

Figure 3. The chemical substance reporting system context model 
a customer. A number of high-level acquisitions by Airbus, Boeing, GE Aerospace and United Technologies Aerospace Systems has resulted in this type of scenario. Figure 5 depicts a supply chain for a typical complex product, showing the flow of products which will require data relating to chemical substances, mixtures and materials to flow along the supply chain.

- Multiple actors: AD articles can be considered as complex articles which can consist of multiple sub-articles joined together to complete the finished article, the article transformation cycle may consist of multiple actors performing various roles.
- Maintaining data ambiguity by using many chemical substances to one specification (many to one), incurs cost inefficiencies of having to (1) checking all data from substance(s) to specification; (2) verifying actual substances used to enable determination of declarable and non-declarable chemical substance(s).

- Adopting a one chemical substance or mixture for one specification approach is the recommended way forward, however it does require $\mathrm{AD}$ companies to understand that it will result in improved configuration management enabling greater substance traceability. The negative aspect will be in the more frequent generation of new engineering drawings.

\begin{tabular}{|c|c|c|c|}
\hline Category & Sub-Category & Examples of Information & \multirow{3}{*}{$\begin{array}{c}\text { Data Ambiguity Caused By } \\
\text { (1) Supplier agreements signed for several } \\
\text { years in advance; (2) Generic contract } \\
\text { clauses for reporting cause confusion; (3) } \\
\text { Not defining precise reporting standards; } \\
\text { (4) Not stating any reporting } \\
\text { requirements. } \\
\end{array}$} \\
\hline \multirow{8}{*}{$\begin{array}{l}\text { Contractual } \\
\text { Documents }\end{array}$} & Supplier Agreements & \begin{tabular}{|c|} 
Specific terms - Article \\
supply (batch sizes) / \\
Definition of obligations \\
\end{tabular} & \\
\hline & Payment Terms & Based on article acceptance & \\
\hline & \multirow{5}{*}{ Required Documents } & Statements of conformity & \multirow{5}{*}{$\begin{array}{l}\text { (1) Data may be spread across multiple sub } \\
\text { systems; (2) Tracing substance(s) across } \\
\text { transformation cycle; (3) Understanding } \\
\text { declarable data and safe use guidance } \\
\text { data to be provided }\end{array}$} \\
\hline & & Material declarations & \\
\hline & & Conflict mineral reporting & \\
\hline & & Safe use guidance & \\
\hline & & Industry reporting standards & \\
\hline & Audit Data & $\begin{array}{l}\text { Auditing supplier processes } \\
\text { and checking required } \\
\text { documentation is in place. }\end{array}$ & $\begin{array}{l}\text { (1) Lack of supplier awareness; (2) Poor } \\
\text { quality control; (3) Data may be spread } \\
\text { across multiple sub-systems. }\end{array}$ \\
\hline \multirow{3}{*}{$\begin{array}{c}\text { Design } \\
\text { Documents }\end{array}$} & $\begin{array}{l}\text { Engineering Design } \\
\text { Documents }\end{array}$ & Dimensional data. & $\begin{array}{c}\text { (1) Identifying substances in articles; } \\
\text { (2) Poor document version control } \\
\text { management. }\end{array}$ \\
\hline & \multirow{2}{*}{ Materials Information } & Material specifications & \multirow{2}{*}{$\begin{array}{l}\text { (1) Identifying substances in processes; } \\
\text { (2) Poor document version control } \\
\text { management. }\end{array}$} \\
\hline & & Process specifications & \\
\hline
\end{tabular}

Figure 4. Chemical substance reporting examples of data ambiguity

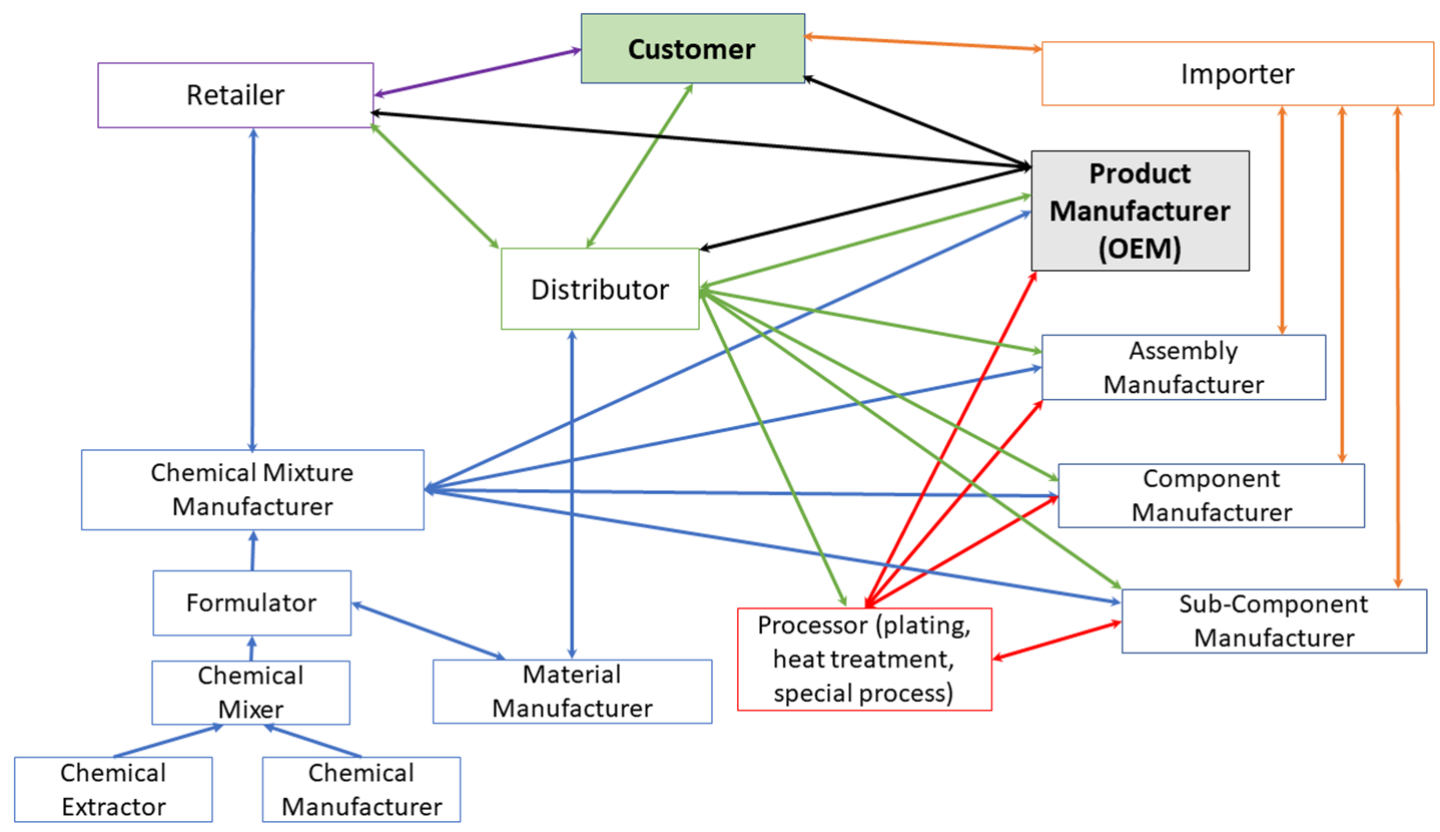

Figure 5. Complex supply chains 


\section{The Chemical Substance Reporting Framework Model}

\subsection{Define Data Elements and Formats}

Examine internal data flows as shown in Figure 3, understand the common attributes which may be passed between sub-systems. List these attributes down as they become the central data elements for the chemical reporting system.

Data formats define the manner in which data is collated and transmitted, from simple spreadsheets, through to CSV, TXT and XML files to parse data between systems in a consistent manner. $\mathrm{XML}$ is deemed to be the most flexible.

\subsection{Understand Your Internal Data Silos}

The following sub-sections examine internal functional areas in terms of progressing from a functional design, purchasing and handling raw materials, manufacture and distribution of articles to consumers.

\section{Design Function Data Elements:}

The design function is observed as being the starting point for the end to end analysis. Figure 6 presents the product definition based on substances, mixtures and materials being assigned to specifications, which would be attached to the article (product) geometry drawings.
1. Chemical substances, mixtures / formulations (2 or more chemical substances); materials (generally defined as a chemicals and mixtures that constitute a physical thing) are identified via specifications.

2. Specifications can be (1) material specifications which identify substances; mixtures / formulations and materials which are present within the final manufactured product; (2) process specifications which identify substances; mixtures / formulations and materials which are used in the process of manufacture (sometimes referred to as process chemicals).

3. Engineering will create applicable machining programs, material handling information, assembly instructions, inspection data; test data to manufacture and release products.

4. Design drawings define product geometry data, which is used by engineering to produce products, identifying applicable material and process specifications.

5. Products are then distributed to consumers, where they may be used on their own, or rolled up into higher level assemblies.

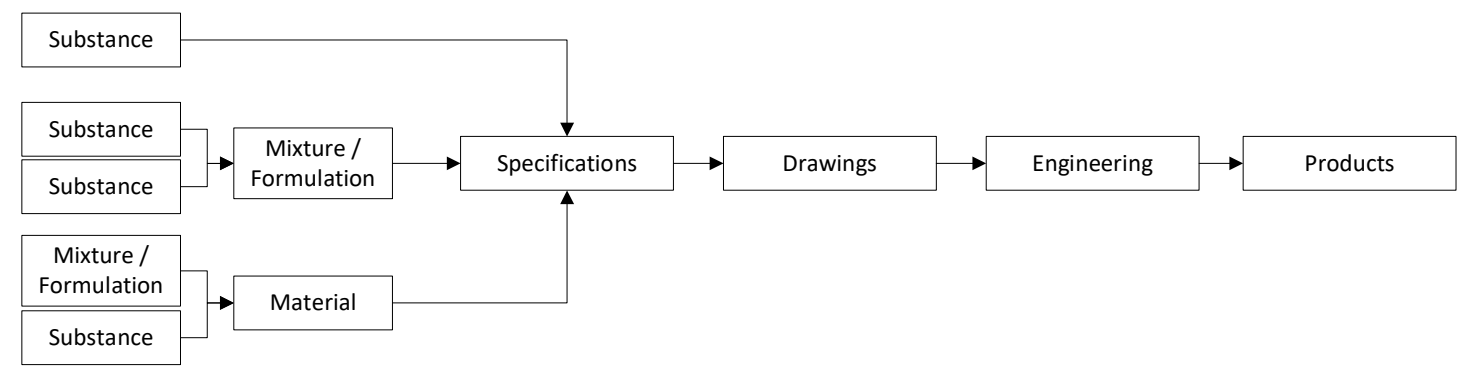

Figure 6. Basic Product Definition

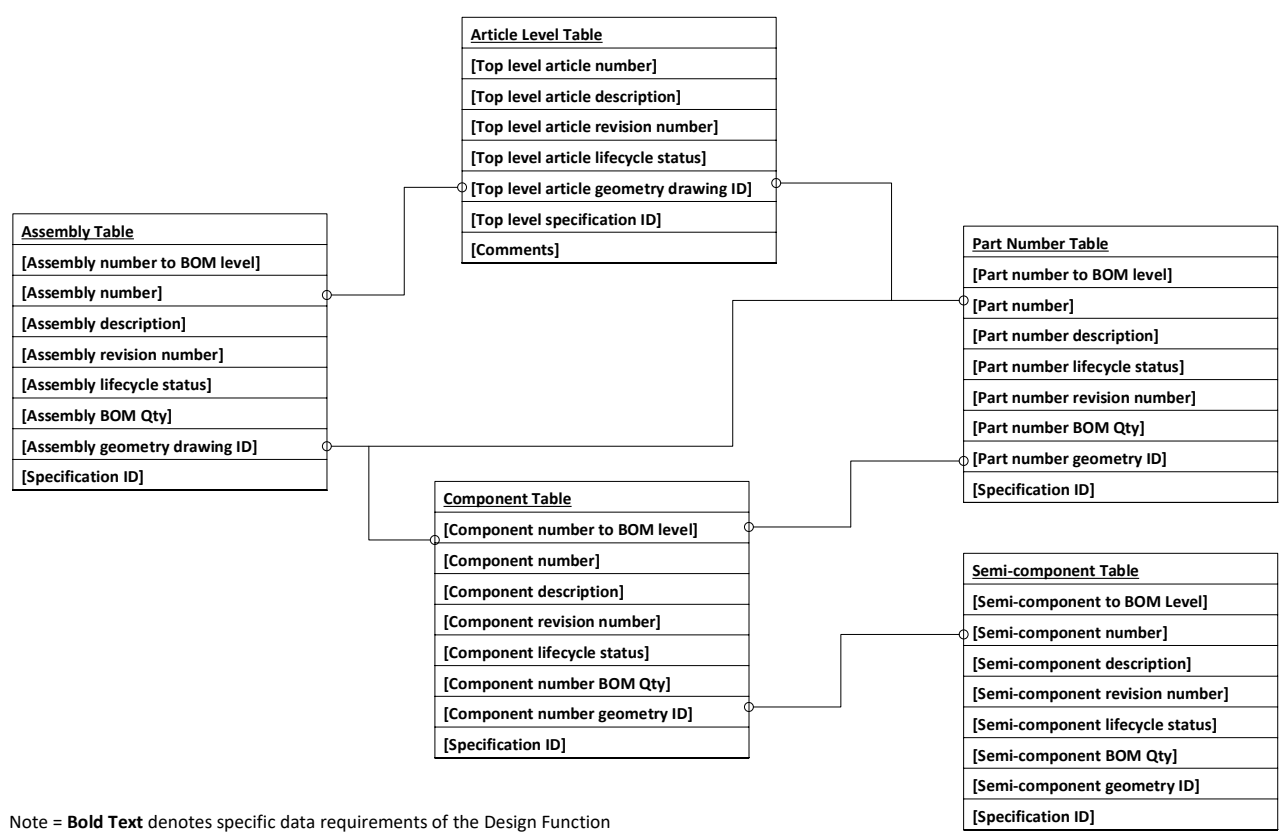

Figure 7. Design Function Data Elements 


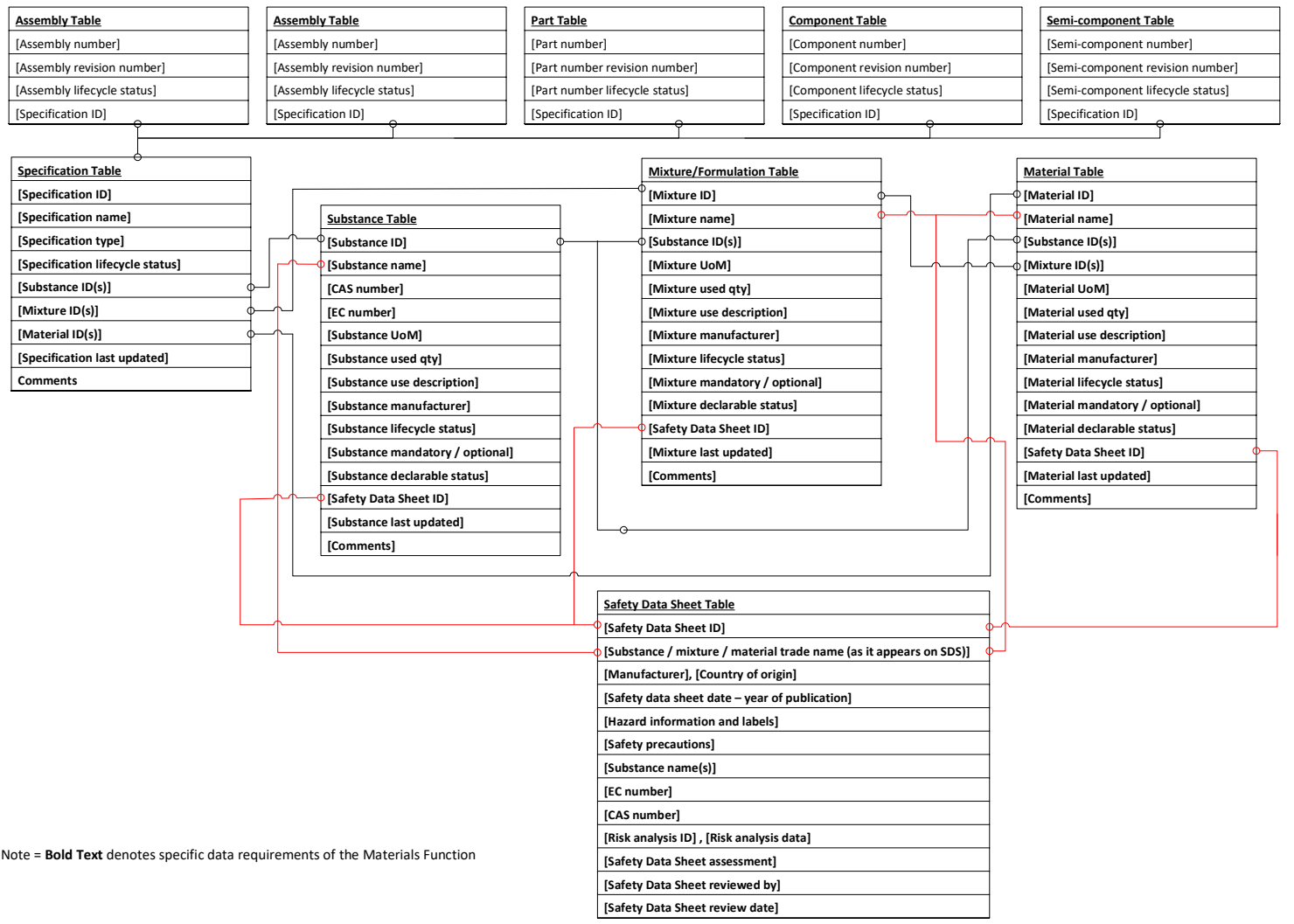

Figure 8. Materials Function Data Elements

The role of the design function is to define the product designs, Figure 7 presents the assumed data requirements / data sources which would occur from the design cycle. The basic premise is that products (top level article numbers) may consist of (1) assemblies (collection of parts and/or components), or; (2) individual part numbers, which may consist of separate components or; (3) components consisting of lower level semicomponents

\section{Materials Function Data Elements}

The role of the materials function is to define chemical substances, mixtures and materials to a given type of specification. The specification types can be either: (1) material specifications the chemical substance, mixture or material appears on the finished product, or; (2) process specifications - chemical substance, mixtures and materials are used as part of the manufacturing cycle.

Figure 8 depicts data utilised by the materials function, the standard substance, mixture and materials are extended using IDs as opposed to enable more granular reporting of a specific usage of a substance, mixture or material, in relation to specification which may be referenced in a geometry drawing created by the design function.

\section{Master Chemical Inventory List}

A master chemical inventory list identifies chemical substances and mixtures physically held in stock. The logic would be to (1) locate all physical chemical substances, mixtures and materials; (2) note the trade name, manufacturer, year of manufacture and country of origin data; (3) input the data into the applicable chemical substance, mixture or material tables; (4) additionally add the SDS/MSDS data to the applicable SDS table; (5) adjust any stock level data within the stores table.

\section{Engineering Function Data Elements}

The role of the engineering is to produce products. To transform substances, mixtures and materials into finished products, the data from the design and material functions is extended as shown in Figure 9 to include machining, testing, and assembly instructions.

A specific make / buy flag would be utilized in conjunction with the purchasing function to determine if an article, assembly, part, component, semi-component is internally produced or externally sourced from the supply chain.

\section{Purchasing Function Data Elements}

The purchasing function is responsible for the procurement of substances, mixtures and materials, from suppliers. The make / buy flag determined by the engineering function determines if a product is manufactured internally or procured from the supply chain. Figure 10 presents the basic data elements required by the chemical reporting system, detailed purchasing related information is expected to maintain within a purchasing system. Sales Function Data Elements

The sales function is responsible for the sale of products (articles) to customers. Figure 11 presents the basic data elements required by the chemical reporting system, detailed sales related information is expected to maintain within a sales system. 


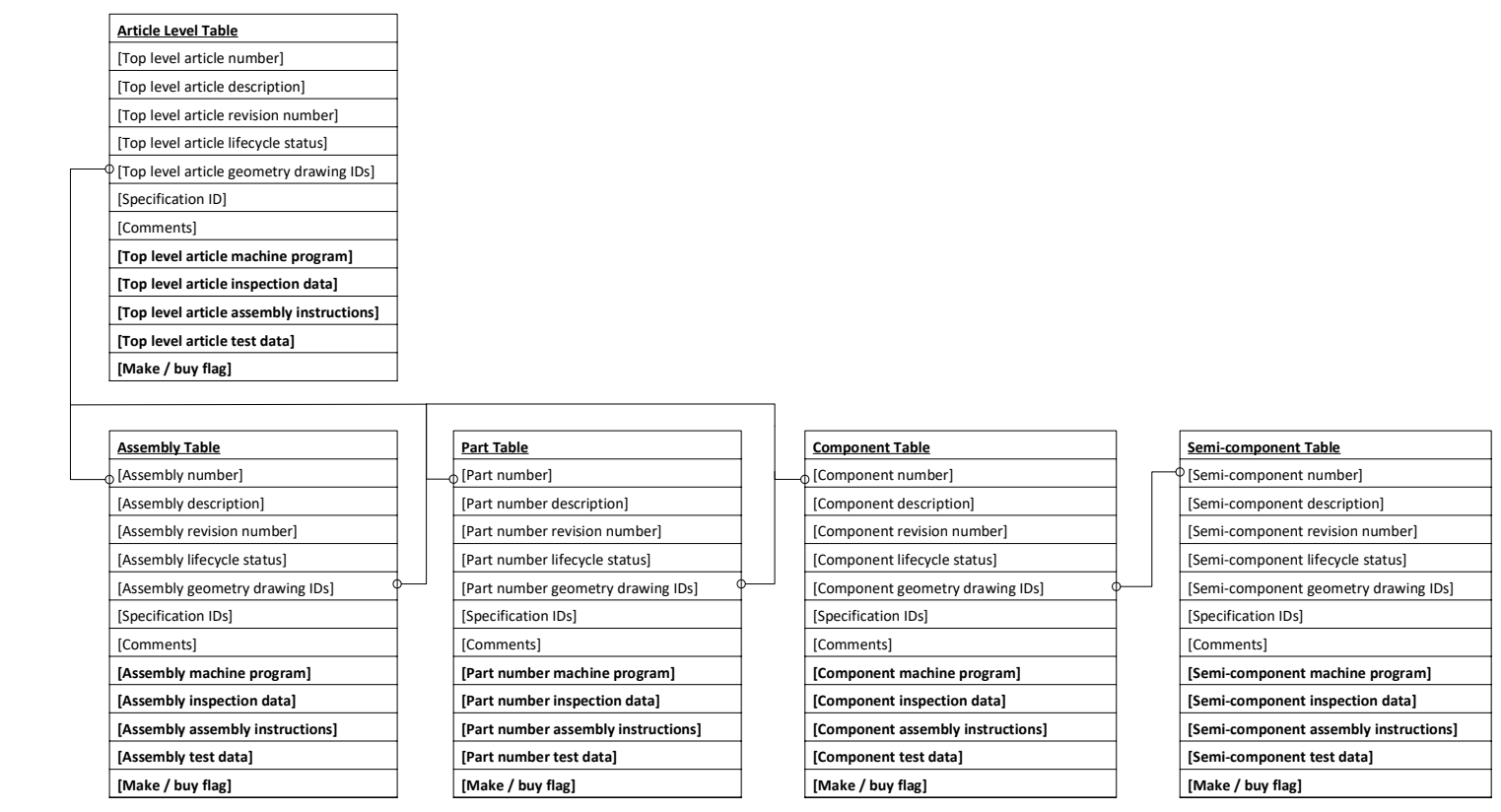

Note $=$ Bold Text denotes specific data requirements of the Engineering Function

Figure 9. Engineering Function Data Elements

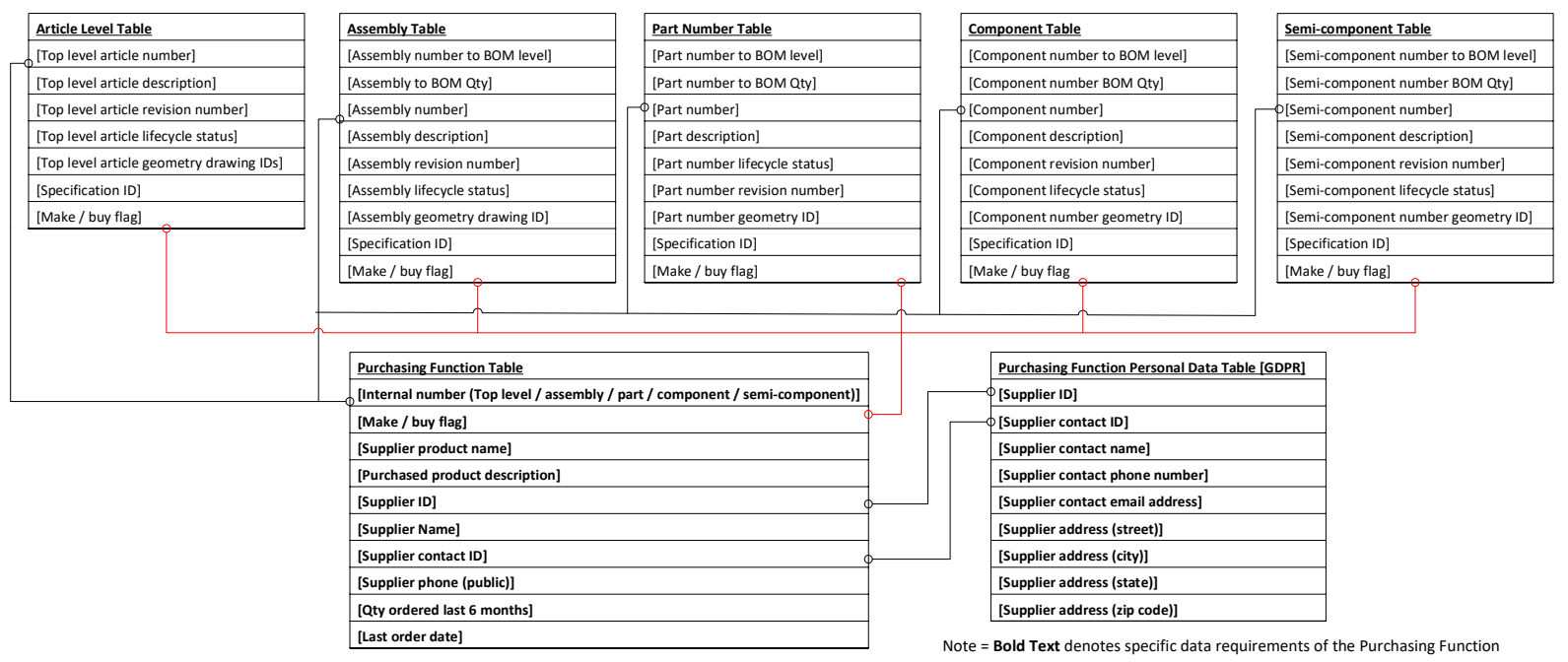

Figure 10. Purchasing Function Data Elements

\begin{tabular}{|l|l|l|}
\hline Article Level Table & Sales Function Table \\
\hline [Top level article number] & [Internal number (Top level)] \\
\hline [Top level article description] & [Customer product number] \\
\hline [Top level article revision number] & [Product description] \\
\hline [Top level article lifecycle status] & [Customer ID] \\
\hline [Top level article geometry drawing IDs] & [Customer contact ID] & [GDPR] \\
\hline [Specification ID] & [Qty sold last 6 months] & [Customer ID] \\
\hline [Customer contact ID] \\
\hline [Customer contact name] \\
\hline [Customer contact phone number] \\
\hline [Customer contact email address] \\
\hline [Customer address (street)] \\
\hline [Customer address (city)] \\
\hline [Customer address (state)] \\
\hline [Customer address (zip code)] \\
\hline
\end{tabular}

Figure 11. Sales Function Data Elements

\section{Stores Function Data Elements}

The stores function is responsible for storage of chemicals, mixtures and materials, releasing them into the engineering function as required. Figure 12 presents the basic data elements required by the chemical reporting system.

www.astesj.com

\section{Transportation Function Data Elements}

The transportation function covers packaging, storing and distribution of the end article to consumers. Figure 13 presents the basic data elements required by the chemical reporting system. 
S.S. Takhar et al. / Advances in Science, Technology and Engineering Systems Journal Vol. 3, No. 5, 459-477 (2018)

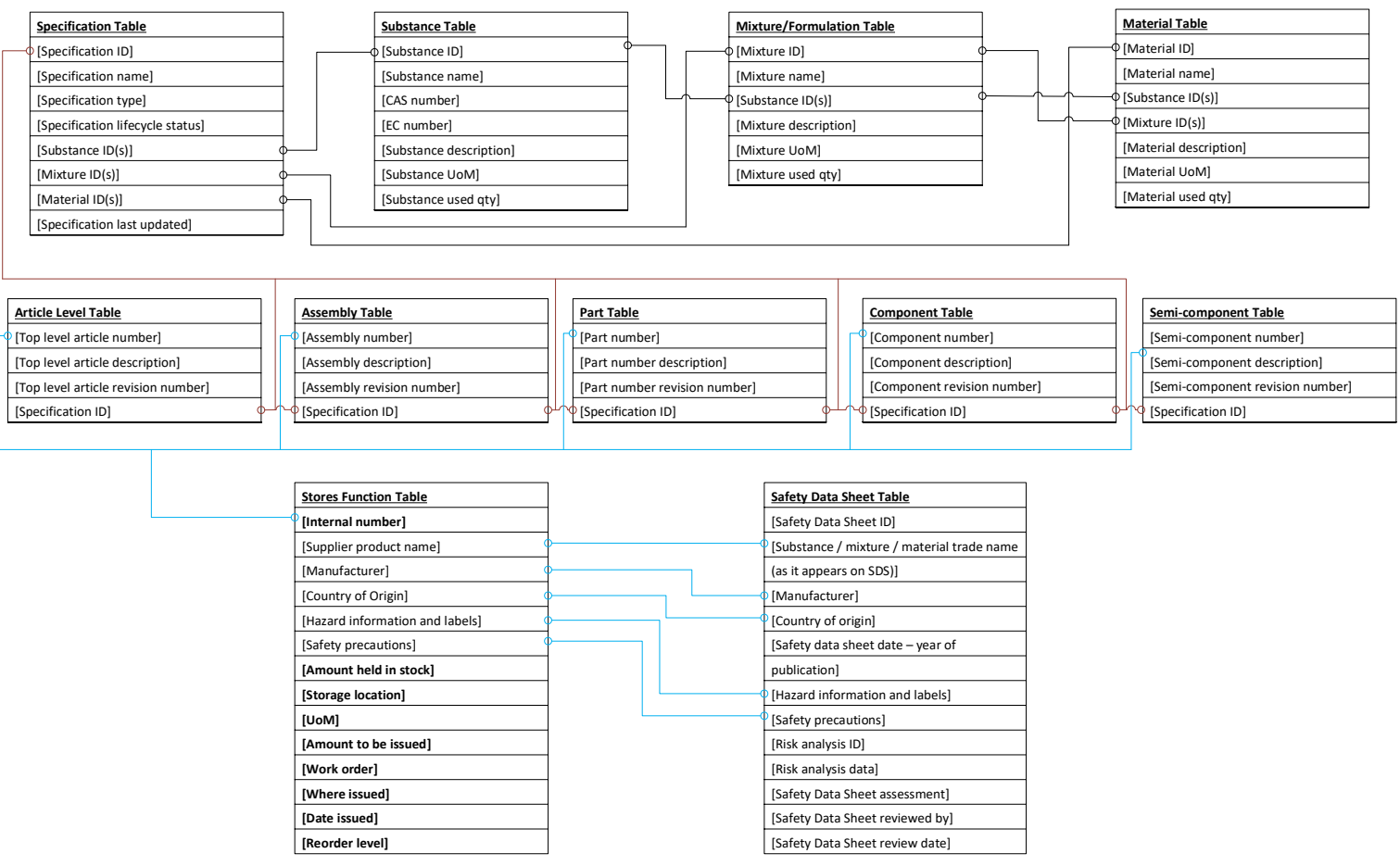

Note $=$ Bold Text denotes specific data requirements of the Stores Function

Figure 12. Stores Function Data Elements

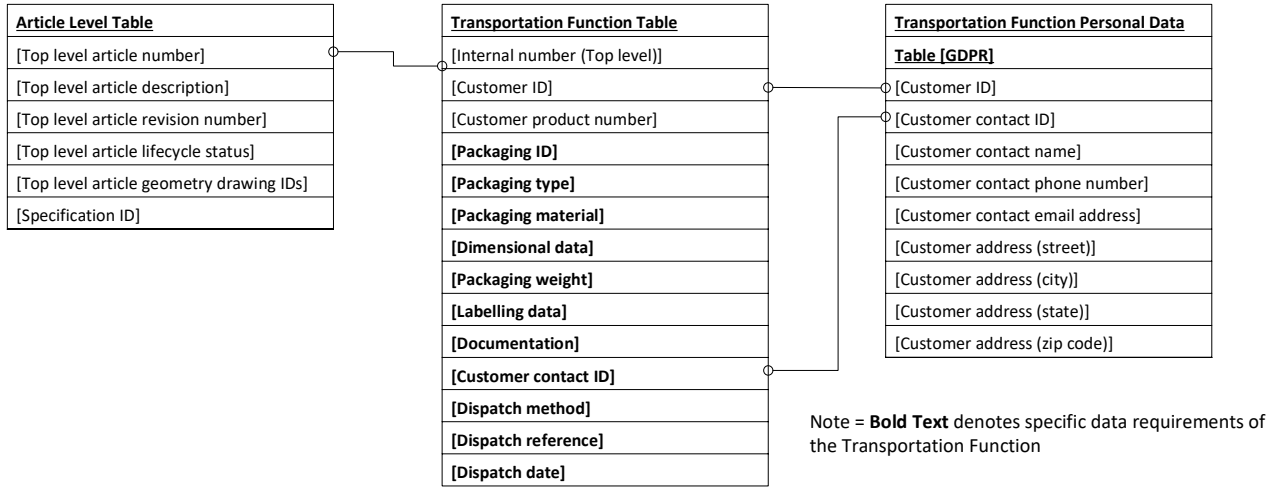

Figure 13. Transportation Function Data Elements

\begin{tabular}{|l|}
\hline Safety Data Sheet Table \\
\hline [Safety Data Sheet ID] \\
\hline [Substance / mixture / material trade name (as it appears on SDS)] \\
\hline [Manufacturer], [Country of origin] \\
\hline [Safety data sheet date - year of publication] \\
\hline [Hazard information and labels] \\
\hline [Safety precautions] \\
\hline [Substance name(s)] \\
\hline [EC number] \\
\hline [CAS number] \\
\hline [Risk analysis ID] , [Risk analysis data] \\
\hline [Safety Data Sheet assessment] \\
\hline [Safety Data Sheet reviewed by] \\
\hline [Safety Data Sheet review date] \\
\hline
\end{tabular}

Note $=$ Bold Text denotes specific data requirements of the Health and Safety Function

Figure 14. Health and Safety Function Data Elements 


\section{Health, Safety and Environment (HSE) Function Data Elements}

The assumption is that the HSE function will review data in conjunction with the Materials Function inputting into the risk analysis and risk actions of the Safety Data Sheet table, as shown in Figure 14:

\section{Quality Function Data Elements}

The role of the quality function is to define procedures for all other functional areas of the business to adhere to, as shown in Figure 15:

\begin{tabular}{|l|}
\hline Quality Function Table \\
\hline [Quality procedure ID] \\
\hline [Applicable function name] \\
\hline [Quality procedure name] \\
\hline [Quality procedure details] \\
\hline [Quality procedure status] \\
\hline [Cross reference standard] \\
\hline [Quality procedure last review date] \\
\hline
\end{tabular}

Note $=$ Bold Text denotes specific data requirements of the Quality Function

Figure 15. Quality Function Data Elements

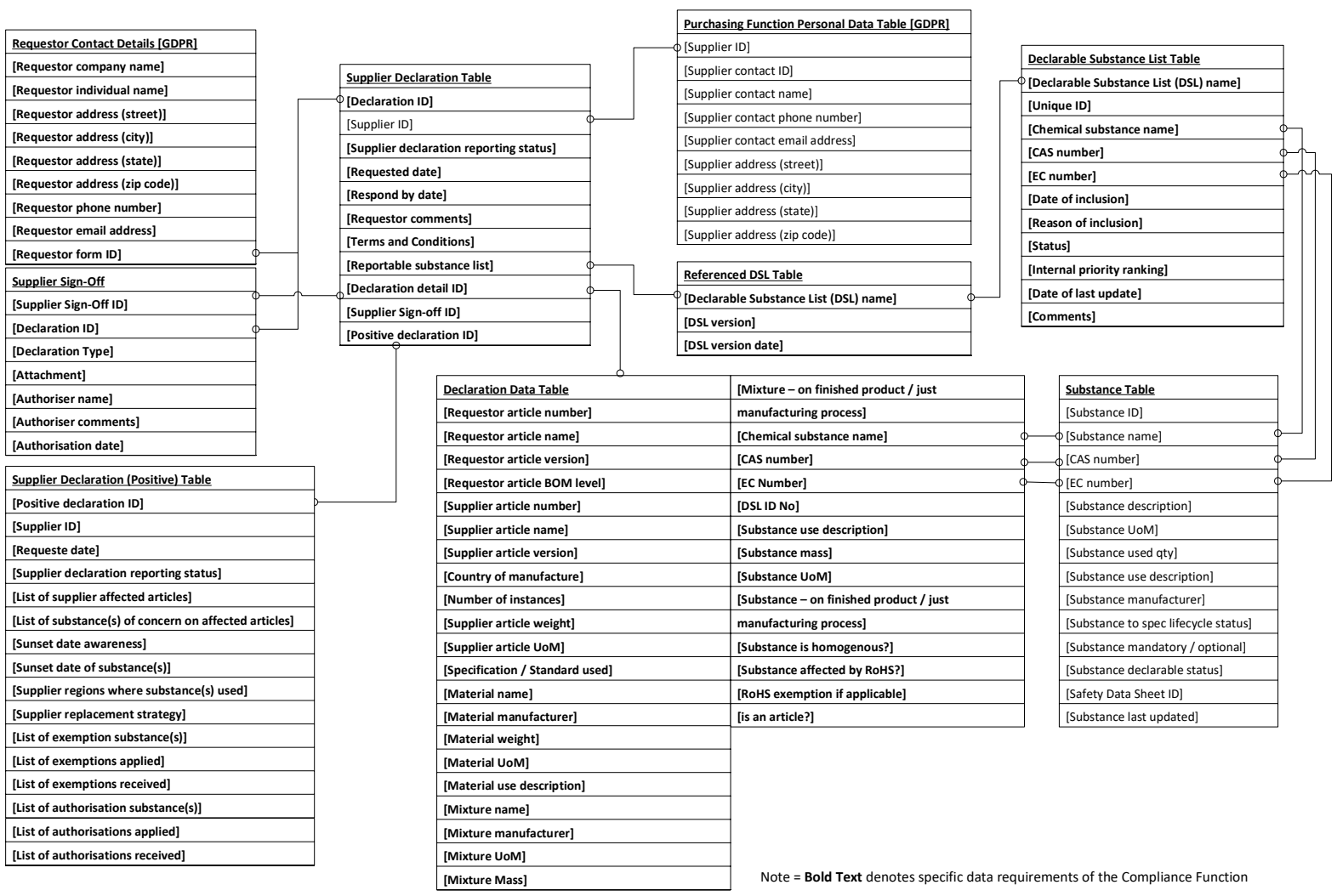

Figure 16. Compliance Function Data Elements for Internal and Procured Products

\begin{tabular}{|l|}
\hline Customer Declaration Table \\
\hline [Declaration ID] \\
\hline [Customer ID] \\
\hline [Customer contact ID] \\
\hline [Internal part number(s)] \\
\hline [Customer part number(s)] \\
\hline [Substances identified on part number(s)] \\
\hline [Chemical regulation - applicable substance list(s)] \\
\hline [Chemical regulation - date of applicable substance list(s)] \\
\hline [Customer declaration statement] \\
\hline [Customer declaration transmitted date] \\
\hline
\end{tabular}

\begin{tabular}{|l|}
\hline Sales Function Personal Data Table [GDPR] \\
\hline [Customer ID] \\
\hline [Customer contact ID] \\
\hline [Customer contact name] \\
\hline [Customer contact phone number] \\
\hline [Customer contact email address] \\
\hline [Customer contact address] \\
\hline
\end{tabular}

Figure 17. Compliance Function Data Elements for Customer Declarations 


\section{Compliance Function Data Elements}

The compliance function plays two pivotal roles: (a) internally manufactured and procured products from the supply chain as shown in Figure 16; (b) generation of appropriate declarations to customers, as shown in Figure 17:

\section{Technical Publications Function Data Elements}

The technical publications function produces user guides, service manuals which are used by end user, as shown in Figure 18:

\subsection{Understand Your External Data Silos}

The following sub-sections examine external data silos which require data to be stored within a chemical substance reporting system, in order to highlight areas of potential business continuity risk:

\section{Develop a Master Chemical Substance List}

Examine all the regions where articles are produced, distributed and sold to consumers. This will inform you of the applicable chemical regulations which may affect your organisation.

Develop the concept of a 'Master Chemical Substance List', which details the chemical substances which are at subject to chemical regulations as shown in Figure 19, also see Appendix 1, Declarable Substance List Table.

\section{Understand Data Flows Across Your Supply Chain}

Figure 7 presented the view that articles are defined by drawings which detail the specifications, which in turn relate to substances, mixtures and materials. Figure 5 depicted a supply chain for a typical complex product. Figure 20 presents an example of how the data may be collated and rolled, as part of the article transformation process across a supply chain:

\begin{tabular}{|c|c|}
\hline Customer Declarations Table & \\
\hline [Customer Name] & \\
\hline [Internal part number(s)] & $\underline{\text { Technical Publications Table }}$ \\
\hline [Customer part number(s)] & [Safe use guidance statement(s)] \\
\hline [Substances identified on part number(s)] & [Compliance statement(s)] \\
\hline [Chemical regulation - applicable substance list(s)] & [User guide(s)] \\
\hline [Chemical regulation - date of applicable substance list(s)] & [Manual name] \\
\hline [Customer declaration statement] & [Manual version] \\
\hline [Customer declaration transmitted date] & [Publications date] \\
\hline
\end{tabular}

Note $=$ Bold Text denotes specific data requirements of the Technical Publications function

Figure 18. Technical Publications Function Data Elements

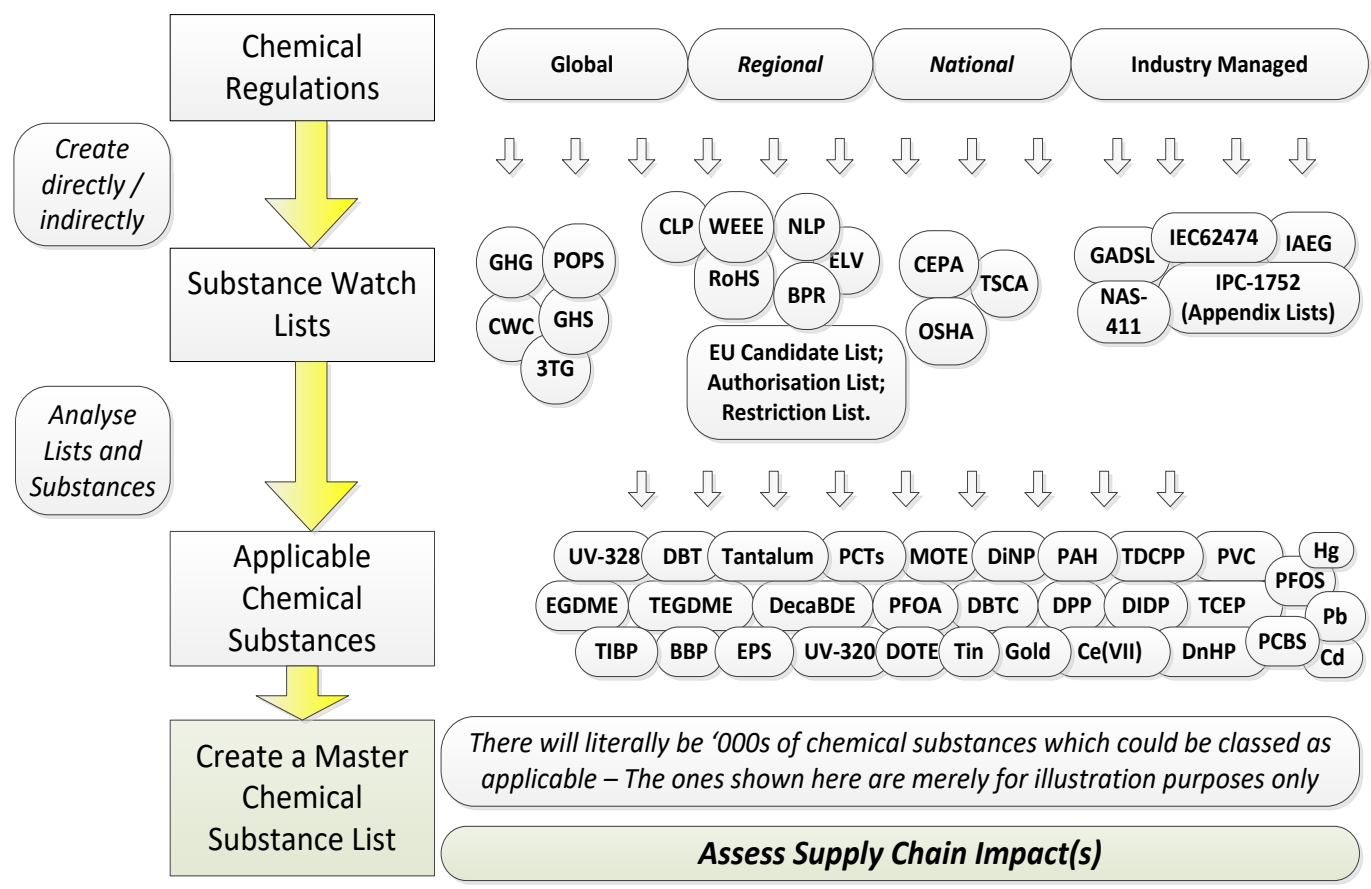

Figure 19. Create a master chemical substance list 


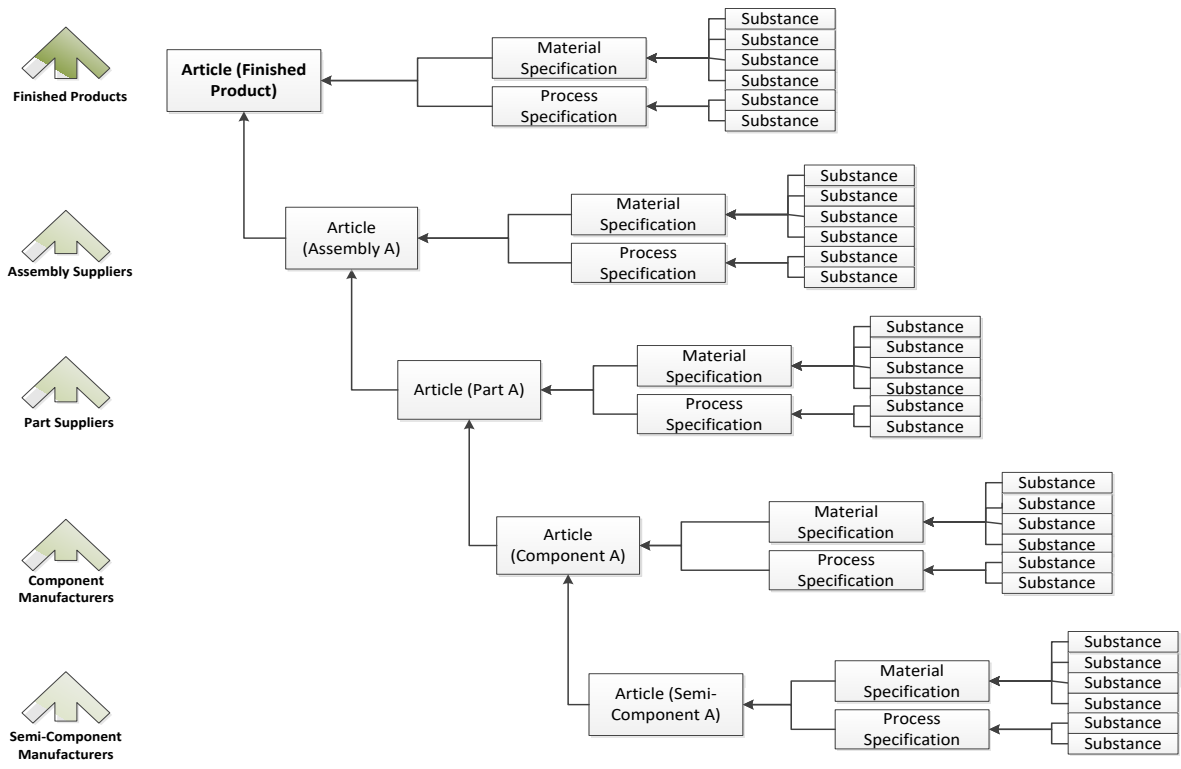

Figure 20. Substance usage tracking within the article transformation process

\section{Develop a Supply Chain Reporting Questionnaire}

A supply chain questionnaire is used to capture data from the supply chain for procured articles. The data elements to be used come from the supplier declaration table elements defined in Figure 17 and also shown in Supplier Declaration Table, Declaration Data Table. The data elements allow for existing data exchange standard templates to be used $[19,20]$.

\section{Define Supply Chain Reporting Tasks}

- Is any supply chain reporting currently being undertaken, if so, how?

- Which functional area will bear responsibility for collecting data from the supply chain? [purchasing / compliance / materials / HSE].

\section{Supply Chain Engagement Tasks}

- Establish early supply chain engagement.

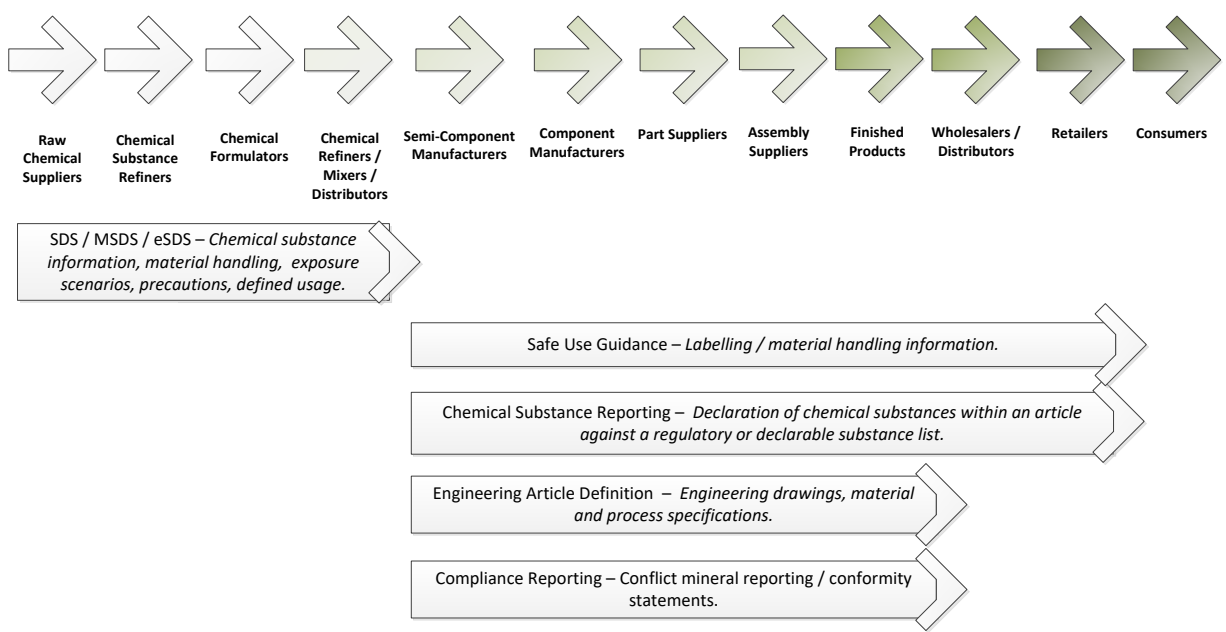

Figure 21. Article transformation cycle: push chemical substance reporting system
- Ensure suppliers contracts state the need for chemical substance reporting as a standard requirement. Agree this requirement with your suppliers.

- Engage with suppliers on any reporting templates to be used, test the use of these templates and make any necessary adjustments.

\section{Supply Chain Training}

- What are the anticipated training needs? - engage with the supply chain to derive requirements.

- Training should inform the supply chain in relation to legal obligations to report chemical substances above any applicable threshold level.

- How is the training expected to be communicated? [online training manuals / printed training matter / webinars /face-to-face meetings]

- Define applicable processes for handling supply chain queries. 


\section{Execute Supply Chain Requests - Push or Pull?}

- Push type systems exist where the lowest supply chain tier flows data from the bottom upward as shown in Figure 21. Push type systems work best in industries which are highly regulated and have well defined articles.

- Pull type systems are used within industries that contain complex articles, for example AD industries. Pull type systems involve the highest tiers in the supply chain initiating the chemical substance reporting requests [28].

\section{Receiving Supply Chain Data Back}

- Supply chain reporting questionnaires transmitted to the supply chain and start to flow back into the organisation.

- A location for storing the supply chain reporting questionnaires should be defined.

- From the storage location, the supply chain reporting questionnaires, should then be processed (using a manual or automated process) and then imported into a target system (where the supplier declaration tables reside).

- The target system may then process the data, rejecting incomplete reporting questionnaires and performing additional processing tasks on successfully imported supply chain reporting questionnaires.

- Back-up copies of processed and rejected files should be stored onto applicable folders, which may then be used to recover records in the event of a system failure.

\section{Discussion}

\subsection{Where Could the Chemical Substance Reporting Data be Stored?}

The intent of the chemical reporting data model is to define the required data elements as shown in Table 1 , needed to enable accurate chemical substance risk analysis against chemical regulation substance risks. The data model is intended to be implemented on a wide range of IT systems including existing engineering design (PDM, PLM), supply chain management (ERP), or onto other platforms (spreadsheets, databases, custom applications, data warehouses or cloud-based systems).

\subsection{Where Could the Chemical Substance Reporting Data be Stored?}

- Develop metrics to: (1) highlight supplier response rates to the supply chain reporting questionnaires; (2) flag data quality issues back to suppliers.

- Using data from (1) substances and mixtures on hand (master chemical inventory list); (2) internally defined products (engineering data), and; (3) supply chain reporting information for procured products; (4) run reporting against all applicable database tables to highlight areas of potential business continuity risk, identifying substances which appear on different regulatory lists and perform the appropriate obligations and actions.

- Develop action plans to act on the business continuity risks identified.

\subsection{Evaluate the Chemical Reporting System}

- Maintain the data within the chemical inventory lists, to ensure an accurate representation of physical substance, mixtures, materials on hand.

- Maintain the master chemical substance list, as chemical regulations are updated on a regular basis.

- Use feedback comments from your supply chain to main any necessary adjustments to the supply chain questionnaire. Adjust as required, and ask the suppliers to identify any areas which impact response rates.

Table 1. Functions, Systems and Related IT System Types

\begin{tabular}{|c|c|c|c|c|c|c|c|c|}
\hline Functional area & $\begin{array}{l}\text { Safety Data } \\
\text { Sheet } \\
\text { System }\end{array}$ & $\begin{array}{l}\text { Material } \\
\text { Specification } \\
\text { System }\end{array}$ & $\begin{array}{l}\text { Compliance } \\
\text { Reporting } \\
\text { (REACH / RoHS } \\
\text { /CMR / CLP / BPR } \\
\text { /ELV / Supply } \\
\text { Chain } \\
\text { Engagement) }\end{array}$ & $\begin{array}{l}\text { CAD } \\
\text { Drawing } \\
\text { System }\end{array}$ & $\begin{array}{l}\text { PDM / } \\
\text { PLM } \\
\text { Systems }\end{array}$ & $\begin{array}{l}\text { ERP } \\
\text { System }\end{array}$ & $\begin{array}{l}\text { Manufacturing } \\
\text { Execution System } \\
\text { (Machining / } \\
\text { Inspection) }\end{array}$ & $\begin{array}{l}\text { Technical } \\
\text { Publications }\end{array}$ \\
\hline $\begin{array}{l}\text { Chemical Substance } \\
\text { Reporting Questionnaire }\end{array}$ & & & $\mathrm{X}$ & & & & & \\
\hline Compliance Function & & & $\mathrm{X}$ & & $\mathrm{X}$ & & & \\
\hline $\begin{array}{l}\text { Master Chemical Substance } \\
\text { list }\end{array}$ & $\mathrm{X}$ & $\mathrm{X}$ & $\mathrm{X}$ & & & & & \\
\hline Health and Safety Function & $\mathrm{X}$ & & $\mathrm{X}$ & & & & $\mathrm{X}$ & \\
\hline Quality Function & $\mathrm{X}$ & $\mathrm{X}$ & $\mathrm{X}$ & & $\mathrm{X}$ & $\mathrm{X}$ & $\mathrm{X}$ & $\mathrm{X}$ \\
\hline Materials Function & $\mathrm{X}$ & $\mathrm{X}$ & $\mathrm{X}$ & & & & & \\
\hline Design Function & & & $\mathrm{X}$ & $\mathrm{X}$ & $\mathrm{X}$ & & & \\
\hline Engineering Function & & & $\mathrm{X}$ & $\mathrm{X}$ & $\mathrm{X}$ & & $\mathrm{X}$ & $\mathrm{X}$ \\
\hline Purchasing Function & & & $\mathrm{X}$ & & $\mathrm{X}$ & $\mathrm{X}$ & & \\
\hline Transportation Function & & & $\mathrm{X}$ & & & $\mathrm{X}$ & & \\
\hline Sales Function & & & & & & $\mathrm{X}$ & & $\mathrm{X}$ \\
\hline
\end{tabular}


- In terms of chemical substance reporting connect with stakeholders in your business and observe feedback comments relating to system reporting, adjusting as required.

\section{Conclusions}

As technological advancements are being made, more and more substances will continue to be developed and released onto the marketplace. Industry will continually strive to develop new product offerings which utilise new chemical substances, mixtures and materials.

As awareness of the risk of specific chemical becomes known, chemical regulators will take the necessary steps to monitor, control and restrict the use of substances which are deemed to be hazardous substances. The net result will over time, be a continually growing list of substances which industry will need to adhere to.

Industry needs to develop chemical reporting systems which observe (1) chemical substances, mixtures and materials held in hand; (2) chemical substances, mixtures and materials internally defined for articles manufactured internally or outsourced to the supply chain; (3) chemical substances, mixtures and materials which are contained with articles procured from the supply chain.

By not implementing a chemical reporting system, industry may not be able to identify the risks of: (1) not clearly understanding details any hazardous substances being used and the application of appropriate safety measures; (2) loss of market access, if no substance or safety information is provided; (3) financial penalties for not identifying regulated chemical substance(s) in a timely manner; (4) supply chain disruption if raw material(s) cannot be sourced as they contain restricted substance(s); (5) potential product failures if a supplier has changed a material / formulation, which affects the performance of a product, which has not been recorded correctly within existing systems; (6) not realising the benefits of sustainability [12], green chemistry [34], recycling and reusing materials as prescribed by the circular economy.

The current framework has examined the need to identify and report on substances within an article, against the chemical regulation substance lists.

The framework model presented in this research paper should allow reporting against a wide range of chemical regulations: EU REACH [5]; EU RoHS [3, 4]; EU Waste Framework Directive [29]; EU Classification; Labelling and Packaging (CLP) [30]; EU Biocidal Properties Reporting (BPR) [31, 32] and EU Conflict Mineral Reporting (CMR) [33] reporting.

The data elements presented in the figures and Table 2 outline the required fields which enable accurate collation of chemical substance data at the material level (appearing on the finished article) and process level (required in order to produce the finished article).

The expectation is that organisations will be able to utilize the findings of this research paper and apply the information to develop appropriate internal chemical reporting systems.
Future extensions to this framework will encompass (i) developing the model with a real-world Delphi study; (ii) developing flow analysis [35] and decision-based modelling [36].

\section{Conflict of Interest}

The authors declare no conflict of interest.

\section{Acknowledgment}

Many thanks to the organizations that participated in the expert interview discussions.

\section{References}

[1] European Commission, Dangerous Substances Directive 67/548/EEC, 1967, [Online]. Available from: http://eur-lex.europa.eu/legalcontent/EN/TXT/?uri=celex:31967L0548.

[2] Regulation of chemicals wiki, last modified 3 July 2018, [Online]. Available from: https://en.wikipedia.org/wiki/Regulation_of_chemicals.

[3] European Commission, EU RoHS Directive 2002/95/EC, 2002, [Online]. Available from: http://eur-lex.europa.eu/legalcontent/EN/TXT/?uri=CELEX:32002L0095.

[4] European Commission, EU RoHS recast Directive 2011/65/EU, 2011 [Online]. Available from: http://eur-lex.europa.eu/legalcontent/EN/TXT/?uri=CELEX:32011L0065

[5] European Commission, EC REACH Regulation EC 1907/2006, 2006 [Online]. Available from: http://eur-lex.europa.eu/legalcontent/EN/TXT/?uri=CELEX:32006R1907.

[6] H. Selin, "Global governance and regional centers: multilevel management of hazardous chemicals and wastes" Procedia - Social and Behavioral Sciences, 14, 40-43. 2011,40-43, doi:10.1016/j.sbspro.2011.03.018.

[7] L. Molander, C. Rudén. "Narrow-and-sharp or broad-and-blunt-Regulations of hazardous chemicals in consumer products in the European Union“ Regulatory Toxicology and Pharmacology, 62(3), 523-531, 2012, doi:10.1016/j.yrtph.2011.11.003.

[8] P. Sivaprakash, L.M. Karthikeyan, S. Joseph "A Study on Handling of Hazardous Chemicals in Engineering Industries" APCBEE Procedia, 9, 187 191, 2014, doi:10.1016/j.apcbee.2014.01.033.

[9] W. Skinner, Manufacturing in the corporate strategy, Wiley, 1978.

[10] L.S. Dias, M.G Ierapetritou, "From process control to supply chain management: An overview of integrated decision making strategies" Computers and Chemical Engineering, 106, 826-835, 2017 doi:10.1016/j.compchemeng.2017.02.006.

[11] M.E Porter, Competitive strategy: techniques for analyzing industries and competitors, The Free Press, 1980.

[12] A. Woinaroschy, "A paradigm-based evolution of chemical engineering“ Chinese Journal of Chemical Engineering, 24(5), 553-557, 2016, doi:10.1016/j.cjche.2016.01.019.

[13] M.F. Ashby, Materials and the Environment Eco-Informed Material Choice, Butterworth-Heinemann imprint of Elsevier Inc, 2009.

[14] L. Molander, et al. "Are chemicals in articles an obstacle for reaching environmental goals? - Missing links in EU chemical management" Science of The Total Environment, 435-436, 280-289, 2012, doi:10.1016/j.scitotenv.2012.07.021.

[15] ECHA candidate list, 2018, [Online]. Available from: https://echa.europa.eu/candidate-list-table.

[16] ECHA authorisations list, 2018, [Online]. Available from: https:/echa.europa.eu/authorisation-list.

[17] ECHA restricted substances list, 2018, [Online]. Available from https://echa.europa.eu/substances-restricted-under-reach.

[18] IMDS Global automotive declarable substance list - background information, 2018, [Online]. Available from: https://public.mdsystem.com/en/web/imdspublic-pages/gadsl.

[19] IPC-1752, 2018 [Online]. Available from: http://www.ipc.org/ContentPage.aspx?pageid=Materials-Declaration\#1752a.

[20] IEC-62474, 2018 [Online]. Available from: http://std.iec.ch/iec62474,.

[21] IAEG AD-DSL, 2018 [Online], Available from: http://www.iaeg.com/workgroups/wg1/addsl/.. 
[22] K. Botsford, "Preparing for product environmental compliance a method for the madness" Product Compliance Engineering (ISPCE), IEEE Symposium on, 2010, doi: 10.1109/PSES.2010.5637803.

[23] D. Cox, A. Sweatman, "Management of restricted substances in consumer products" IEEE Xplore Conference: Environmentally conscious design and inverse manufacturing, 1999. Proceedings. EcoDesign '99: First International Symposium On, doi: 10.1109/ECODIM.1999.747669.

[24] W.E. Deming, Out of the crisis, 2nd ed, MIT Center for Advanced Engineering Study, Massachusetts, 2000.

[25] M.A. Campion, "Doing competencies well: best practices In competency modeling" Personnel Psychology, 64(1), 225-262, 2011, doi: 10.1111/j.17446570.2010.01207.x.

[26] L.C. Müller-Frommeyer. et al, "Introducing competency models as a tool for holistic competency development in learning factories: Challenges, example and future application" Procedia Manufacturing, 9, 307-314. 2017, doi:10.1016/j.promfg.2017.04.015.

[27] P. Hawken, A.B. Lovins, L.H., Lovins, Natural capitalism: The next industrial revolution, Routledge, 2013.

[28] S. Takhar, K. Liyanage, "Top down or Bottom up? - Supply chain engagement for material compliance reporting" Advances in Transdisciplinary Engineering, 6, 77-83, 2017, doi:10.3233/978-1-61499792-4-77.

Table 2. Framework Tables (Names, Fields, Field Types)

\begin{tabular}{|c|c|c|c|c|}
\hline Table & Field Name & $\begin{array}{l}\text { Field } \\
\text { Type }\end{array}$ & $\begin{array}{l}\text { Mandatory / } \\
\text { Optional }\end{array}$ & Comments \\
\hline \multirow[t]{10}{*}{ Article level table } & [Top level article revision number] & nvarchar & Mandatory & \\
\hline & [Top level article lifecycle status] & nvarchar & Optional & \\
\hline & [Top level article geometry drawing ID] & nvarchar & Optional & \\
\hline & [Top level article specification ID] & nvarchar & Optional & \\
\hline & Comments & nvarchar & Mandatory & \\
\hline & [Top level article machine program] & nvarchar & Mandatory & Required by Engineering function [see later] \\
\hline & [Top level article assembly instructions] & nvarchar & Mandatory & Required by Engineering function [see later] \\
\hline & [Top level article inspection data] & nvarchar & Mandatory & Required by Engineering function [see later] \\
\hline & [Top level article test data] & nvarchar & Mandatory & Required by Engineering function [see later] \\
\hline & [Make / buy flag] & nvarchar & Optional & Required by Engineering function [see later] \\
\hline \multirow[t]{14}{*}{ Assembly Table } & [Assembly number to BOM level] & numeric & Mandatory & \\
\hline & [Assembly number] & nvarchar & Mandatory & \\
\hline & [Assembly description] & nvarchar & Mandatory & \\
\hline & [Assembly revision number] & nvarchar & Mandatory & \\
\hline & [Assembly lifecycle status] & nvarchar & Mandatory & \\
\hline & [Assembly BOM qty] & numeric & Mandatory & \\
\hline & [Assembly geometry drawing ID] & nvarchar & Mandatory & \\
\hline & [Assembly specification ID] & nvarchar & Mandatory & \\
\hline & [Comments] & nvarchar & Optional & \\
\hline & [Assembly machine program] & nvarchar & Optional & Required by Engineering function [see later] \\
\hline & [Assembly assembly instructions] & nvarchar & Optional & Required by Engineering function [see later] \\
\hline & [Assembly inspection data] & nvarchar & Optional & Required by Engineering function [see later] \\
\hline & [Assembly test data] & nvarchar & Optional & Required by Engineering function [see later] \\
\hline & [Make / buy flag] & nvarchar & Optional & Required by Engineering function [see later] \\
\hline \multirow[t]{14}{*}{ Part Number Table } & [Part number to BOM level] & numeric & & \\
\hline & [Part number] & nvarchar & & \\
\hline & [Part number description] & nvarchar & & \\
\hline & [Part number revision number] & nvarchar & & \\
\hline & [Part number lifecycle status] & nvarchar & & \\
\hline & [Part number BOM qty] & numeric & & \\
\hline & [Part number geometry drawing ID] & nvarchar & & \\
\hline & [Part number specification ID] & nvarchar & & \\
\hline & [Comments] & nvarchar & & \\
\hline & [Part number machine program] & & Optional & Required by Engineering function [see later] \\
\hline & [Part number assembly instructions] & nvarchar & Optional & Required by Engineering function [see later] \\
\hline & [Part number inspection data] & nvarchar & Optional & Required by Engineering function [see later] \\
\hline & [Part number test data] & nvarchar & Optional & Required by Engineering function [see later] \\
\hline & [Make / buy flag] & nvarchar & Optional & Required by Engineering function [see later] \\
\hline \multirow[t]{6}{*}{ Component Table } & [Component to BOM level] & numeric & Optional & \\
\hline & [Component number] & & Optional & \\
\hline & [Component description] & nvarchar & Optional & \\
\hline & [Component revision number] & nvarchar & Optional & \\
\hline & [Component lifecycle status] & nvarchar & Optional & \\
\hline & [Component BOM qty] & numeric & Optional & \\
\hline
\end{tabular}

[29] EU Waste Framework Directive EU 2018/851, 2018, [Online], Available from: https:/eur-lex.europa.eu/eli/dir/2018/851/oj.

[30] EU CLP, 2018 [Online], Available from: https://echa.europa.eu/regulations/clp/understanding-clp.

[31] EU BPR Regulation 528/2012, 2012 [Online], available from: http://eurlex.europa.eu/LexUriServ/LexUriServ.do?uri=OJ:L:2012:167:0001:0123:en :PDF.

[32] EU BPR Regulation 1062/2014, 2014 [Online], available from: http://eurlex.europa.eu/legalcontent/EN/TXT/PDF/?uri=CELEX:32014R1062\&from=EN

[33] EU Conflict Minerals Regulation, 2017 [Online], available from: http://eurlex.europa.eu/legal-content/EN/TXT/?uri=CELEX:32017R0821.

[34] J.C Charpentier, "What Kind of Modern 'Green' Chemical Engineering is Required for the Design of the 'Factory of Future? "Procedia Engineering, 138, 445-458, 2016, doi:10.1016/j.proeng.2016.02.104.

[35] E. Zschieschang, et al., "Resource Efficiency-oriented Optimization of Material Flow Networks in Chemical Process Engineering" Procedia CIRP, 15, 372-378, 2014, doi:10.1016/j.procir.2014.06.066.

[36] D. Dumas, L.C. Schmidt, P.A. Alexandera, "Predicting creative problem solving in engineering design" Thinking Skills and Creativity, 21,50-66, 2016, pp. 50-66, doi:10.1016/j.tsc.2016.05.002. 
S.S. Takhar et al. / Advances in Science, Technology and Engineering Systems Journal Vol. 3, No. 5, 459-477 (2018)

\begin{tabular}{|c|c|c|c|c|}
\hline Table & Field Name & $\begin{array}{l}\text { Field } \\
\text { Type }\end{array}$ & $\begin{array}{l}\text { Mandatory / } \\
\text { Optional }\end{array}$ & Comments \\
\hline & [Component geometry drawing ID] & nvarchar & Optional & \\
\hline & [Component specification ID] & nvarchar & Optional & \\
\hline & [Comments] & nvarchar & Optional & \\
\hline & [Component machine program] & nvarchar & Optional & Required by Engineering function [see later] \\
\hline & [Component assembly instructions] & nvarchar & Optional & Required by Engineering function [see later] \\
\hline & [Component inspection data] & nvarchar & Optional & Required by Engineering function [see later] \\
\hline & [Component test data] & nvarchar & Optional & Required by Engineering function [see later] \\
\hline & [Make / buy flag] & nvarchar & Optional & Required by Engineering function [see later] \\
\hline \multirow{14}{*}{$\begin{array}{l}\text { Semi-Component } \\
\text { Table }\end{array}$} & [Semi-component to BOM level] & numeric & Optional & \\
\hline & [Semi-component number] & nvarchar & Optional & \\
\hline & [Semi-component description] & nvarchar & Optional & \\
\hline & [Semi-component revision number] & nvarchar & Optional & \\
\hline & [Semi-component lifecycle status] & nvarchar & Optional & \\
\hline & [Semi-component BOM qty] & numeric & Optional & \\
\hline & [Semi-component geometry drawing ID] & nvarchar & Optional & \\
\hline & [Semi-component specification ID] & nvarchar & Optional & \\
\hline & [Comments] & nvarchar & & \\
\hline & [Semi-component machine program] & nvarchar & Optional & Required by Engineering function [see later] \\
\hline & [Semi-component assembly instructions] & nvarchar & Optional & Required by Engineering function [see later] \\
\hline & [Semi-component inspection data] & nvarchar & Optional & Required by Engineering function [see later] \\
\hline & [Semi-component test data] & nvarchar & Optional & Required by Engineering function [see later] \\
\hline & [Make / buy flag] & nvarchar & Optional & Required by Engineering function [see later] \\
\hline \multirow{11}{*}{$\begin{array}{l}\text { Supplier Declaration } \\
\text { Table }\end{array}$} & [Declaration ID] & nvarchar & Mandatory & \\
\hline & [Supplier ID] & nvarchar & Mandatory & \\
\hline & [Supplier declaration reporting status] & nvarchar & Mandatory & \\
\hline & [Requested date] & date & Mandatory & \\
\hline & [Respond by date] & date & Mandatory & \\
\hline & [Requestor comments] & nvarchar & Mandatory & \\
\hline & [Terms and conditions] & nvarchar & Mandatory & \\
\hline & [Reportable substance list] & nvarchar & Mandatory & \\
\hline & [Declaration detail ID] & nvarchar & Mandatory & \\
\hline & [Positive declaration ID] & nvarchar & Optional & \\
\hline & [Supplier sign off ID] & nvarchar & Mandatory & \\
\hline \multirow{9}{*}{$\begin{array}{l}\text { Requestor Contact } \\
\text { Details (GDPR) }\end{array}$} & [Requestor company name] & nvarchar & Mandatory & \\
\hline & [Requestor individual name] & nvarchar & Mandatory & \\
\hline & [Requestor address (street)] & nvarchar & Mandatory & \\
\hline & [Requestor address (city)] & nvarchar & Optional & \\
\hline & [Requestor address (state)] & nvarchar & Optional & \\
\hline & [Requestor address (zip / postal code)] & nvarchar & Optional & \\
\hline & [Requestor phone number] & nvarchar & Optional & \\
\hline & [Requestor email address] & nvarchar & Optional & \\
\hline & [Requestor form ID] & nvarchar & Mandatory & \\
\hline \multirow[t]{3}{*}{ Referenced DSL Table } & [Declarable Substance List (DSL) name] & nvarchar & Mandatory & \\
\hline & [DSL version ID] & nvarchar & Optional & \\
\hline & [DSL version date] & date & Mandatory & \\
\hline \multirow{11}{*}{$\begin{array}{l}\text { Declarable Substance } \\
\text { List Table }\end{array}$} & [Declarable Substance List (DSL) name] & nvarchar & Mandatory & \\
\hline & [Unique ID] & nvarchar & Mandatory & \\
\hline & [Chemical substance name] & nvarchar & Mandatory & \\
\hline & [CAS number] & nvarchar & Optional & \\
\hline & [EC number] & nvarchar & Optional & \\
\hline & [Status] & nvarchar & Mandatory & \\
\hline & [Date of inclusion] & date & Mandatory & \\
\hline & [Reason for inclusion] & nvarchar & Mandatory & \\
\hline & [Internal priority ranking] & nvarchar & Optional & \\
\hline & [Date of last update] & date & Mandatory & \\
\hline & [Comments] & nvarchar & Optional & \\
\hline \multirow{11}{*}{$\begin{array}{l}\text { Declaration Data } \\
\text { Table }\end{array}$} & [Requestor article number] & nvarchar & Mandatory & \\
\hline & [Requestor article name] & nvarchar & Mandatory & \\
\hline & [Requestor article version] & nvarchar & Mandatory & \\
\hline & [Requestor article BOM level] & numeric & Mandatory & \\
\hline & [Supplier article number] & nvarchar & Mandatory & \\
\hline & [Supplier article name] & nvarchar & Mandatory & \\
\hline & [Supplier article version] & nvarchar & Mandatory & \\
\hline & [Country of manufacture] & nvarchar & Mandatory & \\
\hline & [Number of instances] & numeric & Optional & \\
\hline & [Supplier article weight] & numeric & Optional & \\
\hline & [Supplier article UoM] & nvarchar & Optional & \\
\hline
\end{tabular}


S.S. Takhar et al. / Advances in Science, Technology and Engineering Systems Journal Vol. 3, No. 5, 459-477 (2018)

\begin{tabular}{|c|c|c|c|c|}
\hline Table & Field Name & $\begin{array}{l}\text { Field } \\
\text { Type }\end{array}$ & $\begin{array}{l}\text { Mandatory / } \\
\text { Optional }\end{array}$ & Comments \\
\hline & [Specification / Standard used] & nvarchar & Optional & \\
\hline & [Material name] & nvarchar & Optional & \\
\hline & [Material manufacturer] & nvarchar & Optional & \\
\hline & [Material weight] & numeric & Optional & \\
\hline & [Material UoM] & nvarchar & Optional & \\
\hline & [Material use description] & nvarchar & Optional & \\
\hline & [Mixture name] & nvarchar & Optional & \\
\hline & [Mixture manufacturer] & nvarchar & Optional & \\
\hline & [Mixture UoM] & nvarchar & Optional & \\
\hline & [Mixture Mass] & numeric & Optional & \\
\hline & $\begin{array}{l}\text { [Mixture - on finished product / just } \\
\text { manufacturing process] }\end{array}$ & nvarchar & Optional & \\
\hline & [Chemical substance name] & nvarchar & Optional & \\
\hline & [CAS number] & nvarchar & Optional & \\
\hline & [EC Number] & nvarchar & Optional & \\
\hline & [DSL ID No] & nvarchar & Optional & \\
\hline & [Substance use description] & nvarchar & Optional & \\
\hline & [Substance mass] & numeric & Optional & \\
\hline & [Substance UoM] & nvarchar & Optional & \\
\hline & $\begin{array}{l}\text { [Substance }- \text { on finished product / just } \\
\text { manufacturing process] }\end{array}$ & nvarchar & Optional & \\
\hline & [Substance is homogenous?] & nvarchar & Optional & \\
\hline & [Substance affected by RoHS?] & nvarchar & Optional & \\
\hline & [RoHS exemption if applicable] & nvarchar & Optional & \\
\hline & [is an article?] & nvarchar & Mandatory & \\
\hline \multirow{16}{*}{$\begin{array}{l}\text { Supplier Declaration } \\
\text { (Positive) Table }\end{array}$} & [Positive declaration ID] & nvarchar & Mandatory & \\
\hline & [Supplier ID] & nvarchar & Mandatory & \\
\hline & [Requested date] & date & Mandatory & \\
\hline & [Supplier declaration reporting status] & nvarchar & Mandatory & \\
\hline & [List of suppliers affected articles] & nvarchar & Mandatory & \\
\hline & $\begin{array}{l}\text { [List of substance(s) of concern on affected } \\
\text { articles] }\end{array}$ & nvarchar & Optional & \\
\hline & [Sunset date awareness] & nvarchar & Optional & \\
\hline & [Sunset date of substance(s)] & date & Optional & \\
\hline & [Supplier regions where substance(s) used] & nvarchar & Optional & \\
\hline & [Supplier replacement strategy] & nvarchar & Optional & \\
\hline & [List of exemption substance(s)] & nvarchar & Optional & \\
\hline & [List of exemptions applied] & nvarchar & Optional & \\
\hline & [List of exemptions received] & nvarchar & Optional & \\
\hline & [List of authorisation substance(s)] & nvarchar & Optional & \\
\hline & [List of authorisations applied] & nvarchar & Optional & \\
\hline & [List of authorisations received] & nvarchar & Optional & \\
\hline \multirow{11}{*}{$\begin{array}{l}\text { Customer Declaration } \\
\text { Table }\end{array}$} & [Declaration ID] & nvarchar & Optional & \\
\hline & [Customer ID] & nvarchar & Optional & \\
\hline & [Customer contact ID] & nvarchar & Optional & \\
\hline & [Internal part number(s)] & nvarchar & Optional & \\
\hline & [Customer part number(s)] & nvarchar & Optional & \\
\hline & [Substances identified on part number(s)] & nvarchar & Optional & \\
\hline & $\begin{array}{l}\text { [Chemical regulation - applicable substance } \\
\text { list(s)] }\end{array}$ & nvarchar & Optional & \\
\hline & $\begin{array}{l}\text { [Chemical regulation - date of applicable } \\
\text { substance list(s)] }\end{array}$ & date & Optional & \\
\hline & [Substances identified on part number(s)] & nvarchar & Optional & \\
\hline & [Customer declaration statement] & nvarchar & Optional & \\
\hline & [Customer declaration transmitted date] & date & Optional & \\
\hline \multirow{6}{*}{$\begin{array}{l}\text { Technical Publications } \\
\text { Table }\end{array}$} & [Safe use guidance statement(s)] & nvarchar & Mandatory & \\
\hline & [Compliance statement(s)] & nvarchar & Mandatory & \\
\hline & [User guide $(\mathrm{s})$ & nvarchar & Mandatory & \\
\hline & [Manual name] & nvarchar & Optional & \\
\hline & [Manual version] & nvarchar & Optional & \\
\hline & [Publication date] & date & Optional & \\
\hline \multirow[t]{8}{*}{ Specification Table } & [Specification ID] & nvarchar & Mandatory & \\
\hline & [Specification name] & nvarchar & Mandatory & \\
\hline & [Specification type] & nvarchar & Mandatory & \\
\hline & [Specification lifecycle status] & nvarchar & Mandatory & \\
\hline & [Substance ID] & nvarchar & Mandatory & \\
\hline & [Mixture ID] & nvarchar & Optional & \\
\hline & [Material ID] & nvarchar & Optional & \\
\hline & [Specification last updated] & date & Mandatory & \\
\hline
\end{tabular}


S.S. Takhar et al. / Advances in Science, Technology and Engineering Systems Journal Vol. 3, No. 5, 459-477 (2018)

\begin{tabular}{|c|c|c|c|c|}
\hline Table & Field Name & $\begin{array}{l}\text { Field } \\
\text { Type }\end{array}$ & $\begin{array}{l}\text { Mandatory / } \\
\text { Optional }\end{array}$ & Comments \\
\hline & [Comments] & nvarchar & Mandatory & \\
\hline \multirow[t]{14}{*}{ Substance Table } & [Substance ID] & nvarchar & Mandatory & \\
\hline & [Substance name] & nvarchar & Mandatory & \\
\hline & [CAS number] & nvarchar & Mandatory & \\
\hline & [EC number] & nvarchar & Optional & \\
\hline & [Substance UoM] & nvarchar & Mandatory & \\
\hline & [Substance used qty] & numeric & Mandatory & \\
\hline & [Substance use description] & nvarchar & Mandatory & \\
\hline & [Substance manufacturer] & nvarchar & Optional & \\
\hline & [Substance lifecycle status] & nvarchar & Mandatory & \\
\hline & [Substance mandatory / option] & nvarchar & Mandatory & Substance in relation to specification. \\
\hline & [Substance declarable status] & nvarchar & Mandatory & Substance $\diamond$ threshold level. \\
\hline & [Safety Data Sheet ID] & nvarchar & Mandatory & \\
\hline & [Substance last updated] & date & Mandatory & \\
\hline & [Comments] & nvarchar & Optional & \\
\hline \multirow{13}{*}{$\begin{array}{l}\text { Mixture / Formulation } \\
\text { Table }\end{array}$} & [Mixture ID] & nvarchar & Mandatory & \\
\hline & [Mixture name] & nvarchar & Mandatory & \\
\hline & [Substance ID] & nvarchar & Mandatory & \\
\hline & [Mixture UoM] & nvarchar & Mandatory & \\
\hline & [Mixture used qty] & numeric & Mandatory & \\
\hline & [Mixture use description] & nvarchar & Mandatory & \\
\hline & [Mixture manufacturer] & nvarchar & Optional & \\
\hline & [Mixture lifecycle status] & nvarchar & & \\
\hline & [Mixture mandatory / optional] & nvarchar & Mandatory & Mixture / Formulation in relation to specification. \\
\hline & [Mixture declarable status] & nvarchar & Mandatory & $\begin{array}{l}\text { Mixture / Formulation becomes declarable as it contains } \\
\text { a reportable substance }>\text { threshold }\end{array}$ \\
\hline & [Safety data sheet ID] & nvarchar & Mandatory & \\
\hline & [Mixture last updated] & date & Mandatory & \\
\hline & [Comments] & nvarchar & Optional & \\
\hline \multirow[t]{14}{*}{ Material Table } & [Material ID] & nvarchar & Mandatory & \\
\hline & [Material name] & nvarchar & Mandatory & \\
\hline & [Substance ID] & nvarchar & Mandatory & \\
\hline & [Mixture ID] & nvarchar & Optional & \\
\hline & [Material UoM] & nvarchar & Mandatory & \\
\hline & [Material used qty] & numeric & Mandatory & \\
\hline & [Material use description] & nvarchar & Mandatory & \\
\hline & [Material manufacturer] & nvarchar & Optional & \\
\hline & [Material lifecycle status] & nvarchar & Mandatory & \\
\hline & [Material mandatory / optional] & nvarchar & Mandatory & \\
\hline & [Material declarable status] & nvarchar & Mandatory & $\begin{array}{l}\text { Material becomes declarable as it contains a reportable } \\
\text { substance }>\text { threshold }\end{array}$ \\
\hline & [Safety data sheet ID] & nvarchar & Mandatory & \\
\hline & [Material last updated] & date & Mandatory & \\
\hline & [Comments] & nvarchar & Optional & \\
\hline \multirow{16}{*}{$\begin{array}{l}\text { Safety Data Sheet } \\
\text { Table }\end{array}$} & [Safety data sheet ID] & nvarchar & Mandatory & \\
\hline & [Substance / Mixture / Material trade name] & nvarchar & Mandatory & \\
\hline & [Manufacturer] & nvarchar & Mandatory & \\
\hline & [Country of origin] & nvarchar & Mandatory & \\
\hline & [Safety data sheet - Year of publication] & nvarchar & Mandatory & \\
\hline & [Hazard information and labels] & nvarchar & Optional & \\
\hline & [Safety precautions] & nvarchar & Optional & \\
\hline & [Substance name] & nvarchar & Mandatory & \\
\hline & [CAS number] & nvarchar & Mandatory & \\
\hline & [EC number] & nvarchar & Optional & \\
\hline & [Risk analysis ID] & nvarchar & Mandatory & \\
\hline & [Risk analysis data] & nvarchar & Mandatory & \\
\hline & [Safety data sheet assessment] & nvarchar & Optional & \\
\hline & [Safety data sheet reviewed by] & nvarchar & Mandatory & \\
\hline & [Safety data sheet review date] & date & Mandatory & \\
\hline & [Comments] & nvarchar & Mandatory & \\
\hline \multirow[t]{6}{*}{$\begin{array}{l}\text { Purchasing Function } \\
\text { Table }\end{array}$} & [Internal Number] & nvarchar & Mandatory & $\begin{array}{l}\text { Top level article number / assembly number / part } \\
\text { number / component number / semi-component number. } \\
\text { Internal product number. }\end{array}$ \\
\hline & [Make / Buy] & nvarchar & Mandatory & Internally manufactured or sourced from supply chain. \\
\hline & [Supplier product name] & nvarchar & Optional & Supplier part number (SKU) \\
\hline & [Purchased product description] & nvarchar & Optional & \\
\hline & [Supplier ID] & nvarchar & Optional & \\
\hline & [Supplier name] & nvarchar & Optional & \\
\hline
\end{tabular}


S.S. Takhar et al. / Advances in Science, Technology and Engineering Systems Journal Vol. 3, No. 5, 459-477 (2018)

\begin{tabular}{|c|c|c|c|c|}
\hline Table & Field Name & $\begin{array}{l}\text { Field } \\
\text { Type }\end{array}$ & $\begin{array}{l}\text { Mandatory / } \\
\text { Optional }\end{array}$ & Comments \\
\hline & [Supplier contact ID] & nvarchar & Optional & \\
\hline & [Supplier phone (public)] & nvarchar & Optional & \\
\hline & [Qty ordered last 6 months] & nvarchar & Optional & $\begin{array}{l}\text { Extracted from procurement system as an indicator of } \\
\text { purchased volume of product }\end{array}$ \\
\hline & [Last order date] & date & Optional & \\
\hline \multirow{16}{*}{$\begin{array}{l}\text { Purchasing Function } \\
\text { (GDPR) Table } \\
\text { Sales Function Table }\end{array}$} & [Supplier ID] & nvarchar & Mandatory & \\
\hline & [Supplier contact ID] & nvarchar & Mandatory & \\
\hline & [Supplier contact name] & nvarchar & Mandatory & \\
\hline & [Supplier contact phone number] & nvarchar & Optional & \\
\hline & [Supplier contact email address] & nvarchar & Optional & \\
\hline & [Supplier address (street)] & nvarchar & Mandatory & \\
\hline & [Supplier address (city)] & nvarchar & Optional & \\
\hline & [Supplier address (state)] & nvarchar & Optional & \\
\hline & [Supplier address (zip / postal code)] & nvarchar & Optional & \\
\hline & [Internal number] & nvarchar & Mandatory & \\
\hline & [Customer product number] & nvarchar & Mandatory & \\
\hline & [Product description] & nvarchar & Mandatory & \\
\hline & [Customer ID] & nvarchar & Mandatory & \\
\hline & [Customer contact ID] & nvarchar & Mandatory & \\
\hline & [Qty sold last 6 months] & numeric & Optional & \\
\hline & [Last order date] & date & Optional & Date of last sales order \\
\hline \multirow{9}{*}{$\begin{array}{l}\text { Sales Function } \\
\text { (GDPR) Table }\end{array}$} & [Customer ID] & nvarchar & Mandatory & \\
\hline & [Customer contact ID] & nvarchar & Mandatory & \\
\hline & [Customer contact name] & nvarchar & Mandatory & \\
\hline & [Customer contact phone number] & nvarchar & Optional & \\
\hline & [Customer contact email address] & nvarchar & Optional & \\
\hline & [Customer address (street)] & nvarchar & Mandatory & \\
\hline & [Customer address (city)] & nvarchar & Optional & \\
\hline & [Customer address (state)] & nvarchar & Optional & \\
\hline & [Customer address (zip / postal code)] & nvarchar & Optional & \\
\hline \multirow[t]{14}{*}{ Stores Function Table } & [Internal number] & nvarchar & Mandatory & \\
\hline & [Supplier product name] & nvarchar & Optional & \\
\hline & [Manufacturer] & nvarchar & Mandatory & \\
\hline & [Country of origin] & nvarchar & Mandatory & \\
\hline & [Hazard information and labels] & nvarchar & Optional & \\
\hline & [Safety precautions] & nvarchar & Mandatory & \\
\hline & [Storage location] & nvarchar & Mandatory & \\
\hline & {$[\mathrm{UoM}]$} & nvarchar & Mandatory & \\
\hline & [Amount held in stock] & numeric & Mandatory & \\
\hline & [Last work order] & nvarchar & Optional & Last work order where issued \\
\hline & [Amount issued] & numeric & Optional & \\
\hline & [Where issued] & nvarchar & Optional & \\
\hline & [Date issued] & date & Optional & \\
\hline & [Reorder level] & numeric & Mandatory & \\
\hline \multirow{14}{*}{$\begin{array}{l}\text { Transportation } \\
\text { Function Table }\end{array}$} & [Internal number] & nvarchar & Mandatory & \\
\hline & [Customer ID] & nvarchar & Mandatory & \\
\hline & [Customer product number] & nvarchar & Optional & \\
\hline & [Packaging ID] & nvarchar & Optional & \\
\hline & [Packaging Type] & nvarchar & Mandatory & \\
\hline & [Packaging Material] & nvarchar & Optional & \\
\hline & [Dimensional Data] & nvarchar & Optional & \\
\hline & [Packaging weight] & nvarchar & Optional & \\
\hline & [Labelling data] & nvarchar & Optional & \\
\hline & [Documentation] & nvarchar & Mandatory & \\
\hline & [Customer contact ID] & nvarchar & Mandatory & \\
\hline & [Dispatch method] & nvarchar & Mandatory & \\
\hline & [Dispatch reference] & nvarchar & Mandatory & \\
\hline & [Dispatch date] & date & Mandatory & \\
\hline \multirow{10}{*}{$\begin{array}{l}\text { Transportation } \\
\text { Function (GDPR) } \\
\text { Table }\end{array}$} & [Customer ID] & nvarchar & Mandatory & \\
\hline & [Customer contact ID] & nvarchar & Mandatory & \\
\hline & [Customer contact name] & nvarchar & Mandatory & \\
\hline & [Customer contact phone number] & nvarchar & Optional & \\
\hline & [Customer contact email address] & nvarchar & Optional & \\
\hline & [Customer address (street)] & nvarchar & Mandatory & \\
\hline & [Customer address (city)] & nvarchar & Optional & \\
\hline & [Customer address (state)] & nvarchar & Optional & \\
\hline & [Customer address (zip / postal code)] & nvarchar & Optional & \\
\hline & [Quality procedure ID] & nvarchar & Mandatory & \\
\hline
\end{tabular}


S.S. Takhar et al. / Advances in Science, Technology and Engineering Systems Journal Vol. 3, No. 5, 459-477 (2018)

\begin{tabular}{|l|l|l|l|l|}
\hline Table & Field Name & $\begin{array}{l}\text { Field } \\
\text { Type }\end{array}$ & $\begin{array}{l}\text { Mandatory / } \\
\text { Optional }\end{array}$ & Comments \\
\hline \multirow{3}{*}{$\begin{array}{l}\text { Quality Function } \\
\text { Table }\end{array}$} & [Applicable function name] & nvarchar & Mandatory & \\
\cline { 2 - 4 } & {$[$ Quality procedure name] } & nvarchar & Mandatory & \\
\cline { 2 - 5 } & {$[$ Quality procedure details] } & nvarchar & Mandatory & \\
\cline { 2 - 5 } & {$[$ Quality procedure status] } & nvarchar & Optional & \\
\cline { 2 - 5 } & {$[$ Cross reference standard] } & nvarchar & Optional & \\
\cline { 2 - 4 } & [Quality procedure last reviewed date] & Date & Mandatory & \\
\hline
\end{tabular}

